\title{
Analysis of SARS-CoV-2 Omicron Neutralization Data up to 2021-12-22
}

Antonia Netzl ${ }^{1,{ }^{\star}}$, Sina Tureli ${ }^{1,{ }^{*}}$, Eric LeGresley ${ }^{1,{ }^{*}}$, Barbara Mühlemann ${ }^{2,3}$, Samuel H. Wilks ${ }^{1}$, Derek J. Smith ${ }^{1, * *}$

${ }^{1}$ Center for Pathogen Evolution, Dept of Zoology, University of Cambridge, UK

${ }^{2}$ Institute of Virology, Charité-Universitätsmedizin Berlin, corporate member of Freie Universität Berlin, Humboldt-Universität zu Berlin, and Berlin Institute of Health, 10117 Berlin, Germany ${ }^{3}$ German Centre for Infection Research (DZIF), partner site Charité, 10117 Berlin, Germany

"These authors contributed equally, ${ }^{* *}$ Correspondence:Derek Smith djs200@cam.ac.uk

\begin{abstract}
The rapid spread of the Omicron SARS-CoV-2 variant (B.1.1.529) resulted in international efforts to quickly assess its escape from immunity generated by vaccines and previous infections. Numerous laboratories published Omicron neutralization data as preprints and reports. The understandable limitations and variability in such rapid reporting of early results however made it difficult to make definitive statements about the data. Here, we aggregate and analyze Omicron neutralization data from 23 reporting laboratories up to 2021-12-22. There are enough data to identify multiple trends and make two definitive points. First, in twice-vaccinated individuals, titer fold drop of Omicron relative to wild type is more than $19 x$, likely substantially more given the number of measurements below the limit of detection of the assay. Second, out to one month post third vaccination with an mRNA vaccine, or twice vaccinated after an earlier infection, the titer fold drop to Omicron is substantially less at approximately $7 x$. This substantially lower fold drop and somewhat higher titers after 3rd vaccination are strong early evidence for the utility of booster vaccination.
\end{abstract}




\section{Introduction}

The Omicron variant (B.1.1.529) was first reported to WHO on November 24, 2021 and has been spreading quickly. To prepare for a new COVID-19 wave caused by Omicron, it is important to get an early read on its ability to escape immunity acquired through vaccination, factoring in different vaccine types and vaccination strategies. Multiple groups have quickly produced data with serum sets and variants to hand and released them, mostly as preprints or preliminary reports, for public use. In this manuscript we analyze the available data to identify trends in Omicron's escape across laboratories and assays which might be explained by infection and vaccination history. We present our results as forest-plot based visual analysis to facilitate their joint interpretation. The aggregated data as basis for our analysis is available as a publicly accessible google sheet document ${ }^{1}$.

\section{Results}

We have analyzed Omicron virus neutralization data from 23 laboratories which are either in preprint form or are otherwise in the public domain. These data include neutralization of Omicron by different vaccine sera and sera of individuals infected with the wild type, Alpha, Beta or Delta variant. A variety of neutralization assays and cell types were used by the different laboratories (Table 1).

\section{Omicron titer fold drop relative to wild type titers}

Fold drops in neutralization of Omicron compared to wild type in different vaccine sera are shown in Figure 1, grouped by serum type and ordered by decreasing fold drop. We categorize the data across studies into serum groups by their infection or vaccination history. In the "2x Vax" group ( $n=44)$ we include double vaccinated individuals, independent of vaccine type, and single dose 
Johnson \& Johnson (J\&) vaccinated individuals as a single $\mathrm{J} \& \mathrm{~J}$ dose is the recommended vaccination regime. The convalescent sera ("Conv") group $(n=21)$ contains sera from individuals that were infected with a SARS-CoV-2 variant, the "Inf $+2 \times$ Vax" $(n=9)$ sera from individuals that were vaccinated after being infected. Similarly, the " $2 x$ Vax + Inf" group $(n=4)$ contains sera from individuals that were infected subsequently to their vaccinations. FInally, the " $3 x$ Vax" group $(n=19)$ consists of triple vaccinated sera.

The largest serum group consists of double vaccinated or J\&J single dose vaccinated individuals. This twice-vaccinated regroup has the widest spread and largest uncertainty in fold drop of Omicron neutralization compared to wild type. We find an approximately $19 x$ fold drop in the double vaccinated group. However, the majority of fold drops in double vaccinees are likely greater than the point estimate given here due to many Omicron titers being below the limit of detection for the assay. Further, fold drops less than 2 are often the result of low titers against the reference antigen, as in Balazs ${ }^{19} \mathrm{~J} \& \mathrm{~J}$ recently vaccinated. The average fold drop in the double vaccinated group is thus likely substantially greater than the mean of $19 x$ seen here.

There is a strikingly different pattern in the group of triple vaccinated individuals. Here, almost all Omicron titers were detectable and fold drops lower and more narrowly distributed than in double vaccinees. The average fold drop from wild type (WT) is $7 \mathrm{x}$. The majority of sera from three times vaccinated individuals were, however, taken within one month of the last vaccination and thus do not provide information of how these titers will develop over time.

The infected + double vaccinated cohort is closest to the triple vaccinated in spread and mean fold drop, with the majority of Omicron titers being above the detection threshold and an average fold drop from wild type of 12x. Data from studies that examined the neutralization reduction in vaccinated and later infected individuals suggest a similar pattern. Noteworthy, the study by 
Cong et al., ${ }^{14}$ (Liu) that describes the largest fold drop to WT is in this group, resulting in the largest mean fold drop of $25 x$, but samples tested in this study were obtained from individuals with an acute Delta infection three days after hospitalization.

Generally, infection without vaccination appears to result in the second highest average fold drop from wild type (20x). In this serum group, the second largest overall fold drop was reported by Cong et al. ${ }^{14}(\mathrm{Liu})$, again in sera from individuals three days after hospitalization but with a wild type infection.

Fold drops grouped by vaccine manufacturer show that point estimate uncertainty is lowest in mRNA vaccinees and infected + mRNA vaccinated individuals (Extended Data Figure 1). Alternative grouping strategies by neutralization assay reveal no substantial difference in mean fold drops between pseudovirus (PV) and live-virus (LV) neutralization assays in the double and triple vaccinated serum groups (2x Vax LV: 19.6x, PV: 18.6x; 3x Vax LV: 8.8x, PV: 6.5x) (Extended Data Figure 2). No trend is discernible based on cell type but HEK293T-ACE2 cells most frequently resulted in measurements below detection threshold (Extended Data Figure 3). Fold drops against variants other than WT can be found in Extended Data Figure 4. 
bioRxiv preprint doi: https://doi.org/10.1101/2021.12.31.474032; this version posted January 7, 2022. The copyright holder for this preprint (which was not certified by peer review) is the author/funder. All rights reserved. No reuse allowed without permission.
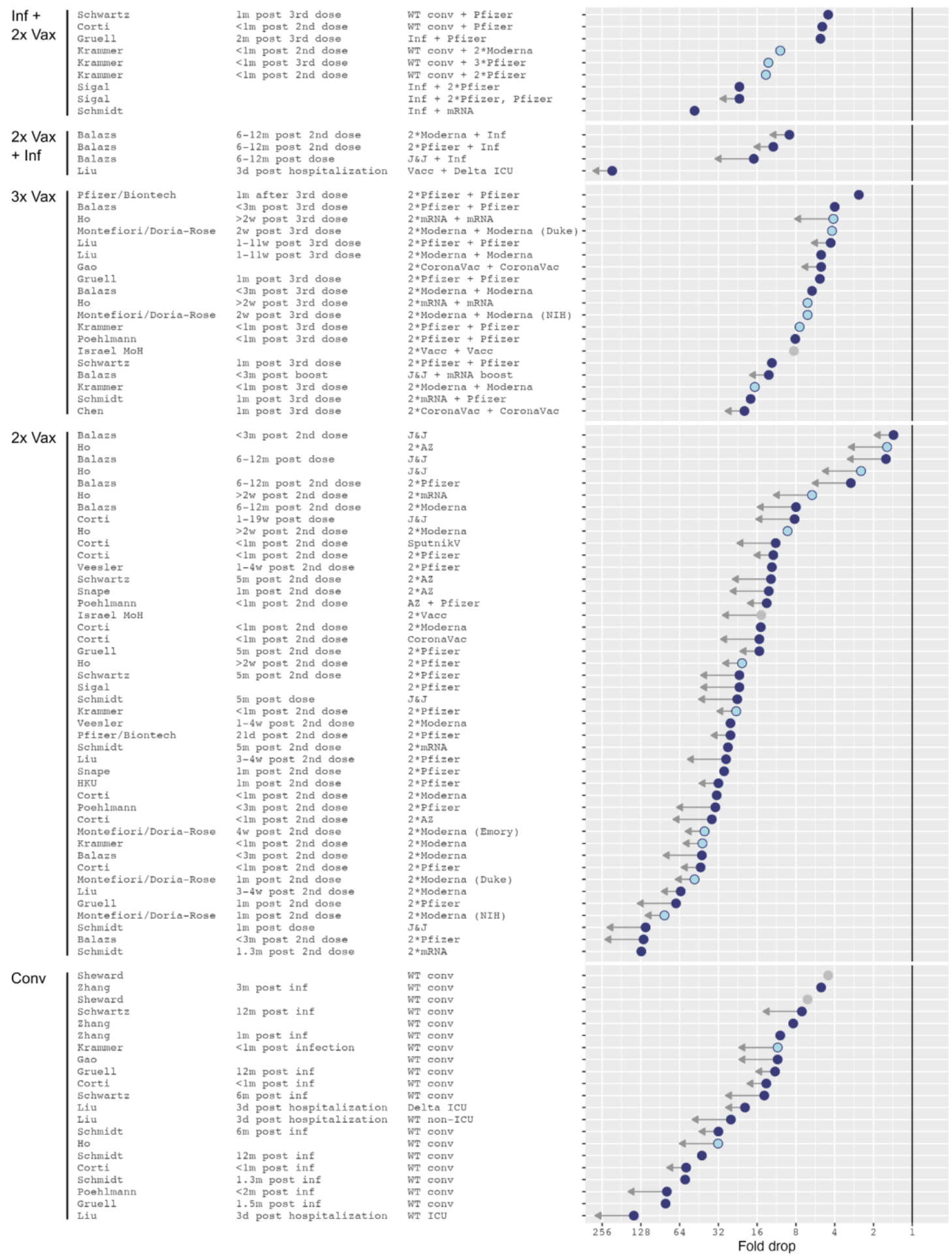

Figure 1: Omicron fold drops relative to wild type. Arrows indicate uncertainties in the point estimate due to titers below the limit of detection (LOD) of the assay. A short arrow marks measurements with less than half of Omicron titers below the assay's limit of detection (LOD), or conversely reference antigen titers at or higher than the LOD. Long arrows mark measurements with more than approximately $80 \%$ of Omicron titers below the LOD. Light blue dots show NIH SAVE laboratories, gray dots mark data points for which the reference antigen was not stated in the manuscript and is here assumed to be Wu-1. The solid vertical line marks no fold change. 


\section{Omicron titers relative to wild type titers}

In addition to fold drops relative to wild type titers, we report Omicron titers obtained by applying the fold drop shown in Figure 1 to the wild type GMTs. The point estimates grouped by serum type and ordered by decreasing wild type titer are presented in Figure 2.

It might be that the substantially lower fold drop in the three times vaccinees compared to two times vaccinees is because higher titers in three times vaccinees are being underreported, either by laboratories not titrating to the endpoint, or because of a high-titer non-linearity in the assay - something discussed in multiple forums. It can be clearly seen however from the data as presented in Figure 2 that in the triple vaccinated cohort, the fold drop from wild type to Omicron is independent of titer magnitude against wild type as evident by horizontal bars of similar length between WT and Omicron point estimates. Thus the substantially lower fold-drop in three times vaccinees is likely real.

On average, the highest titers against both WT and Omicron are recorded in the infected + vaccinated serum group (estimated WT GMT: 5674 , Omicron GMT: 464). In the triple vaccinated group, mean titer estimates against WT and Omicron are at $40 \%$ and $70 \%$ of the mean values in the Inf $+2 x$ Vax cohort, respectively (WT GMT: 2238, Omicron GMT: 332). In both serum groups, the majority of Omicron titers are above the assay detection threshold and hence Omicron titer estimates are largely reliable.

In contrast, due to many Omicron titers below the detection threshold in the remaining groups, the point estimates and thus also the mean Omicron titers are likely overestimated. Although WT titers in the group of vaccinated + infected sera were well detectable (WT GMT: 1583), due to below threshold titers the average Omicron titer of 57 is likely higher than the real value. 
Similar patterns of high WT titers but barely detectable titers against Omicron occur in the convalescent (WT GMT: 647, Omicron GMT: 28) and 2x Vax chorts (WT GMT: 491, Omicron GMT: 26).

In the $2 x$ Vax cohort, WT titers after a single J\&J dose or double SputnikV, CoronaVac tend to be lower than after two vaccinations with AstraZeneca. The mRNA vaccine sera generally exhibit the highest WT titers in this group. Further, we see that Liu ${ }^{14}$ 's ICU samples $(2 x$ Vax + Infected \& Conv serum group), which were taken three days after hospitalization, have the highest WT titers in their respective group and many thresholded Omicron titers, explaining the large fold drops observed in Figure 1. 

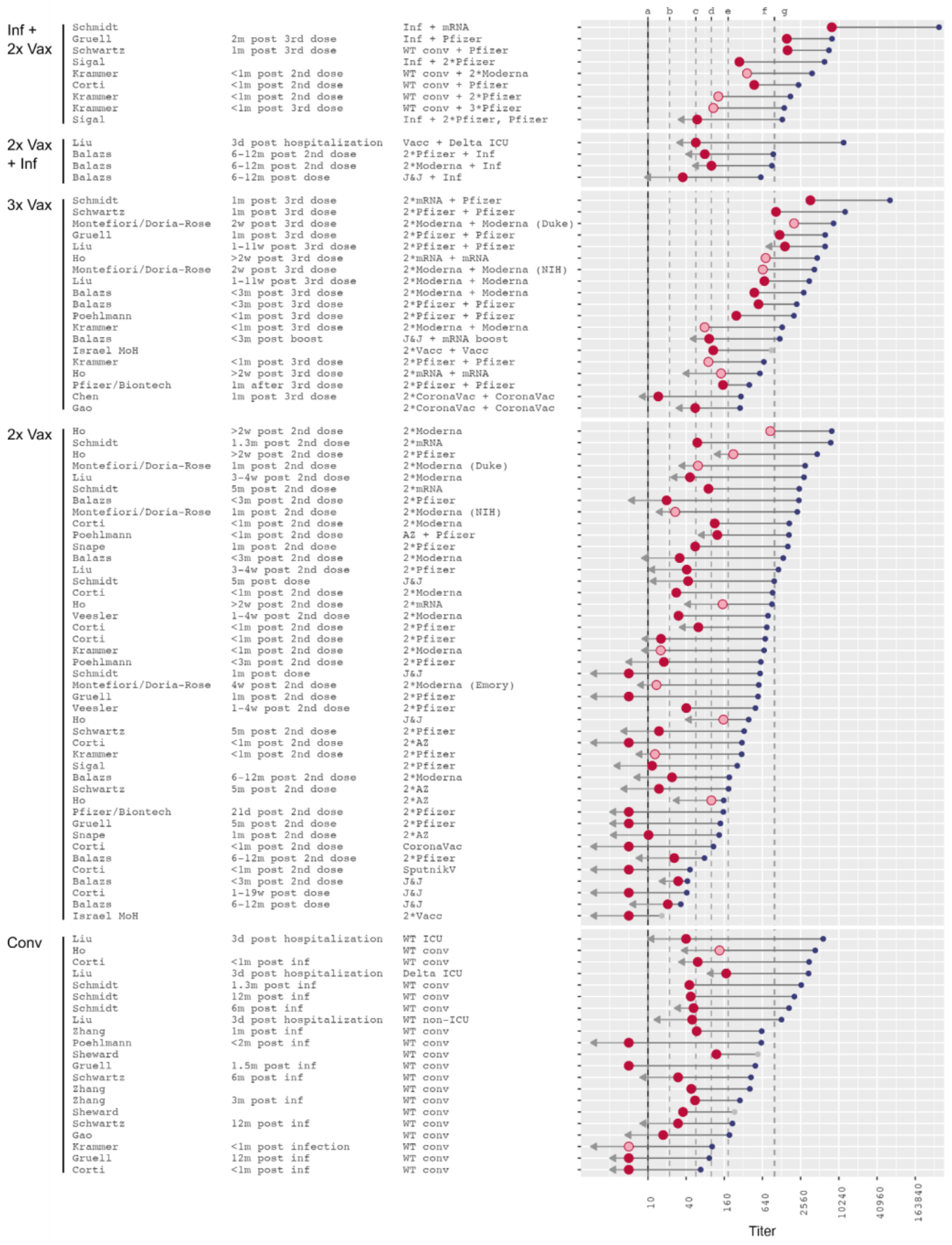

Figure 2: Omicron titers relative to wild type ordered by decreasing wild type titers. Large red dots indicate Omicron titers and small blue dots indicate wild type titers. Omicron titers were obtained by applying the fold drop given in Figure 1 to wild type titers, corresponding to the horizontal bar connecting wild type and Omicron point estimates. Arrows indicate uncertainties in the point estimate. A short arrow marks measurements with less than half of Omicron titers below the assay's limit of detection (LOD), or conversely reference antigen titers at or higher than the LOD. Long arrows mark measurements with more than approximately $80 \%$ of Omicron titers below the LOD. Dashed lines mark thresholds of protection against symptomatic disease after vaccination with two doses of Moderna (a,d,f,g $)^{28}$ or AstraZeneca (b,c,e,f) $)^{27}$ assessed by pseudovirus neutralization assay (a $78 \% \mathrm{VE}, \mathrm{b} 60 \% \mathrm{VE}$, c $70 \%$ VE, d $91 \%$ VE, e $80 \%$ VE, f $90 \%$ VE, g 96\% VE). Pink dots show NIH SAVE laboratories. 
To estimate the protection against symptomatic disease, we compare the titers here against correlates of protection against symptomatic disease as determined by pseudovirus neutralization studies after two doses of AstraZeneca ${ }^{27}$ or Moderna ${ }^{28}$. It must be noted however that it is not yet clear that VE estimates from these studies will apply to Omicron. Figure 3 shows titer estimates ordered by decreasing Omicron titers.

The mean Omicron titer estimate in the Inf $+2 x$ Vax group suggests protection against symptomatic disease is $>80 \%$ for Omicron as reported after two doses of AstraZeneca ${ }^{27}(80 \%$ VE at ID50=185) or Moderna ${ }^{28}(91 \%$ VE at ID50=100). In this group, the lowest Omicron titer would still confer $70 \%$ protection. In the triple vaccinated group, titer estimates within 1 month of the third dose for both WT and Omicron are high enough to suggest $>80 \%$ protection against symptomatic disease. All Omicron titers, except for the Chen ${ }^{10} 3 x$ CoronaVac (BBIBP-CorV) estimate, are above the $70 \%$ VE threshold when we disregard uncertainties in the point estimates. As a result of large uncertainties and the question whether VE estimates apply to Omicron, we refrain from inferring correlates of protection in the remaining groups.

When comparing pseudovirus (PV) and live-virus (LV) neutralization assays, we see that laboratories that used pseudovirus assays to determine Omicron neutralization reported almost two times higher WT and Omicron GMTs in the 2x Vax group (Omicron LV GMT: 14, PV GMT: 31; WT LV GMT: 299, PV GMT: 570) and almost 3 times higher Omicron titers in triple vaccinees (Omicron LV GMT: 167, PV GMT: 453; WT LV GMT: 1428, PV GMT: 2630) than groups that performed live-virus assays (Extended Data Figures 5 \& 6).

Omicron titers estimated against other variants than WT can be found in Extended Data Figure 7. In the supplement, we further show the titer estimates grouped by alternative strategies, 
bioRxiv preprint doi: https://doi.org/10.1101/2021.12.31.474032; this version posted January 7, 2022. The copyright holder for this preprint (which was not certified by peer review) is the author/funder. All rights reserved. No reuse allowed without permission.

including vaccine type, assay type and cell type ordered by Omicron and WT titer (Extended Data Figures 5-9). 
bioRxiv preprint doi: https://doi.org/10.1101/2021.12.31.474032; this version posted January 7, 2022. The copyright holder for this preprint (which was not certified by peer review) is the author/funder. All rights reserved. No reuse allowed without permission.

\begin{tabular}{|c|c|}
\hline $\begin{array}{l}\text { Inf }+ \\
2 x \text { Vax }\end{array}$ & $\begin{array}{l}\text { Schmidt } \\
\text { Schwartz } \\
\text { Gruell } \\
\text { Corti } \\
\text { Krammer } \\
\text { Sigal } \\
\text { Krammer } \\
\text { Kramuer } \\
\text { Sigal }\end{array}$ \\
\hline $\begin{array}{l}2 x \text { Vax } \\
+ \text { Inf }\end{array}$ & $\begin{array}{l}\text { Balazs } \\
\text { Balazs } \\
\text { Liu } \\
\text { Balazs }\end{array}$ \\
\hline $3 x \operatorname{Vax}$ & $\begin{array}{l}\text { Schmidt } \\
\text { Montefiori/Doria-Rose } \\
\text { Liu } \\
\text { Gruell } \\
\text { Schwartz } \\
\text { Ho } \\
\text { Liu } \\
\text { Montefiori/Doria-Rose } \\
\text { Balazs } \\
\text { Balazs } \\
\text { Poehlmann } \\
\text { Pfizer/Biontech } \\
\text { Ho } \\
\text { Israel MoH } \\
\text { Balazs } \\
\text { Krammer } \\
\text { Krammer } \\
\text { Gao } \\
\text { Chen }\end{array}$ \\
\hline $2 x \operatorname{Vax}$ & $\begin{array}{l}\text { Ho } \\
\text { Ho } \\
\text { Ho } \\
\text { Ho } \\
\text { Poehlmann } \\
\text { Corti } \\
\text { Ho } \\
\text { Schmidt } \\
\text { Corti } \\
\text { Montefiori/Doria-Rose } \\
\text { Schmidt } \\
\text { Snape } \\
\text { Liu } \\
\text { Schmidt } \\
\text { Liu } \\
\text { Veesler } \\
\text { Balazs } \\
\text { Veesler } \\
\text { Balazs } \\
\text { Corti } \\
\text { Montefiori/Doria-Rose } \\
\text { Balazs } \\
\text { Balazs } \\
\text { Balazs } \\
\text { Balazs } \\
\text { Poehlmann } \\
\text { Corti } \\
\text { Kramumer } \\
\text { Schwartz } \\
\text { Schwartz } \\
\text { Montefiori/Doria-Rose } \\
\text { Kramuner } \\
\text { Sigal } \\
\text { Snape } \\
\text { Pfizer/Biontech } \\
\text { Schmidt } \\
\text { Gruell } \\
\text { Grueli } \\
\text { Corti } \\
\text { Corti } \\
\text { Corti } \\
\text { Corti } \\
\text { Israel MoH }\end{array}$ \\
\hline Conv & $\begin{array}{l}\text { Liu } \\
\text { Ho } \\
\text { Sheward } \\
\text { Corti } \\
\text { Zhang } \\
\text { Zhang } \\
\text { Schmidt } \\
\text { Liu } \\
\text { Zhang } \\
\text { Schmidt } \\
\text { Schmidt } \\
\text { Liu } \\
\text { Sheward } \\
\text { Schwartz } \\
\text { Schwartz } \\
\text { Gao } \\
\text { Gruell } \\
\text { Gruell } \\
\text { Kramumer } \\
\text { Poehlmann } \\
\text { Corti }\end{array}$ \\
\hline
\end{tabular}

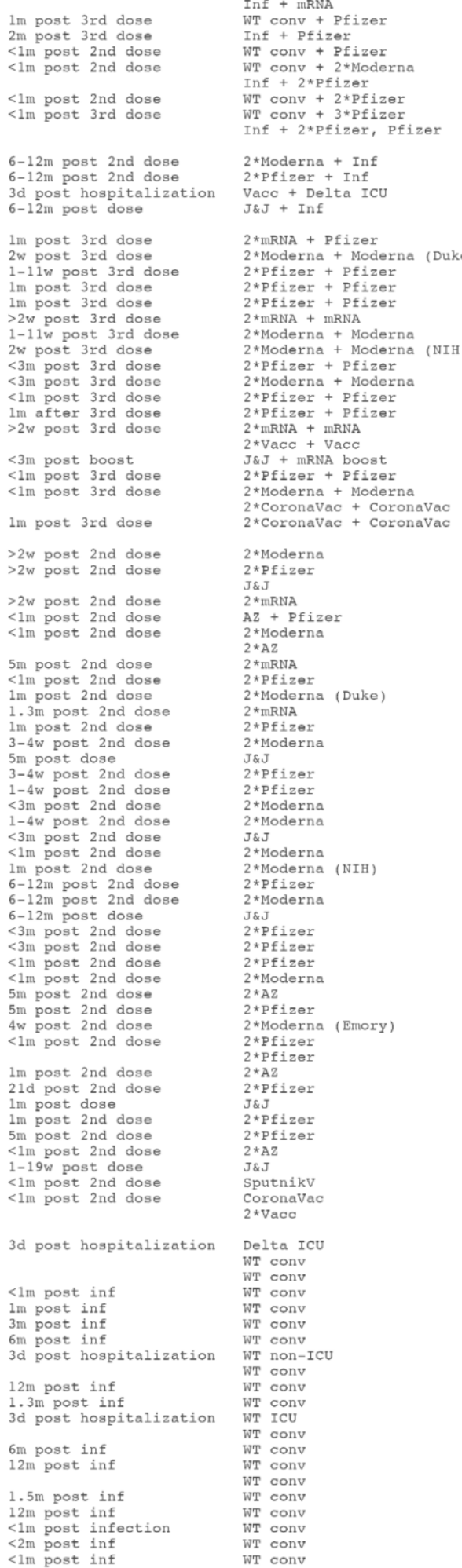

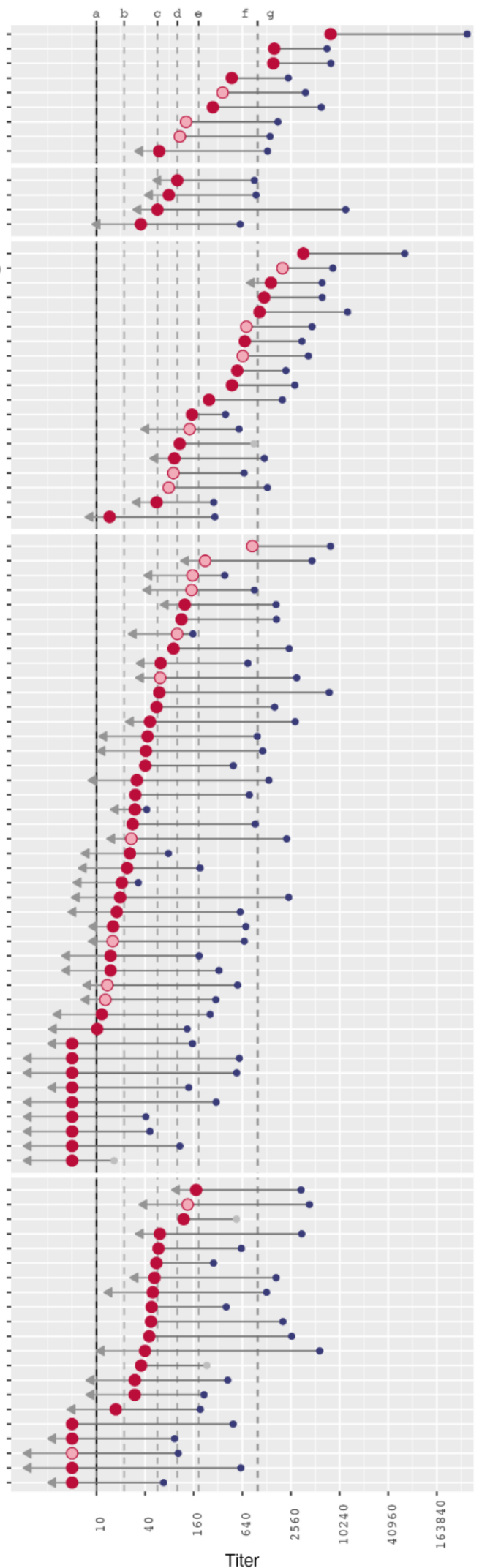

Titer

Figure 3: Omicron titers relative to wild type ordered by decreasing Omicron titers. Same as Figure 2, but datasets within each group are sorted by Omicron titer instead of wild type titer. 


\section{Discussion}

Two definitive statements can be made from the aggregation of the early data on Omicron virus neutralization data. Sera from individuals who have been vaccinated twice or infected once show generally more than a $19 x$ fold drop of titers, whereas people who have been vaccinated three times or have been vaccinated + infected show an average of approximately $7 x$ fold drop of titers. This reduced titer drop in three times vaccinated individuals appears to be real and not an artifact of an upper limit of detection of the assay. Almost all of the data in the three times vaccinated group are, however, from sera taken within 1 month of the last vaccination, whether this reduced titer drop will persist over time is yet to be determined. Nevertheless, the substantially lower fold drop and somewhat higher titers after a third vaccination are strong early evidence for the utility of booster vaccination at increasing virus neutralization titers against Omicron, and thus potentially at increasing vaccine efficacy.

Some of the data we use are estimates as numerical data or individual repeat data is not available at this early stage. In such cases we extracted individual data points from figures using Webplotgitizer ${ }^{3}$ and this will lead to some inaccuracies. Censored titers below an assay's detection threshold further increase these uncertainties. The fold drops for the twice vaccinated group, for example, is likely substantially greater than the $19 x$ numeric estimate. However, a deflation of fold drops due to wild type titers at or above an assay's limit of detection is unlikely, as visible in Figure 2. The differences between Omicron and WT titers are roughly consistent across studies in the triple vaccinated and infected + vaccinated cohort and are not influenced by the absolute magnitude of WT titers.

In terms of titer and fold drop estimates, the triple vaccinated group is more similar to the infected + vaccinated than to the double vaccinated group. It needs to be noted that in these studies the 
time point of most recent vaccination was less than 3 months prior to serum collection, in the majority of cases 1 month prior to collection. How titers against Omicron develop over time is yet to be seen..

While we did not see a difference in fold drops from WT to Omicron neutralization depending on assay type, the titers reported in studies that used pseudovirus neutralization assays exceeded titers measured by live-virus neutralization. Omicron titers in double vaccinees were on average 2 times higher in pseudovirus than in live-virus assays, and almost 3-fold higher in triple vaccinees. This could, however, be a consequence of the sera types investigated using the different assays. The majority of PV sera came from mRNA vaccinated individuals, whereas livevirus assay tested sera contained sera from J\&J, SputnikV and CoronaVac vaccinated individuals which tend to induce lower titers than mRNA vaccines (Extended Data Figure 9). Nevertheless, in Feng et al.'s ${ }^{27}$ study of vaccine efficacy (VE) against symptomatic disease after two doses of AstraZeneca, they reported lower VE at higher titers in live-virus neutralization vs. pseudovirus neutralization assays. 


\section{References}

1. Aggregated Omicron neutralization data.

https://docs.google.com/spreadsheets/d/1K4qzjtMk0pGLWOrLe8HZlqVPN67GkNCK/edit.

2. Rohatgi, A. WebPlotDigitizer - Extract data from plots, images, and maps.

https://automeris.io/WebPlotDigitizer/.

3. Wilks, S. meantiter. https://github.com/shwilks/meantiter.

4. Cele, S. et al. SARS-CoV-2 Omicron has extensive but incomplete escape of Pfizer BNT162b2 elicited neutralization and requires ACE2 for infection. medRxiv (2021) doi:10.1101/2021.12.08.21267417.

5. Sheward, D. J., et al. Preliminary Report - Early release, subject to modification: Quantification of the neutralization resistance of the Omicron Variant of Concern. (2021).

6. Wilhelm, A., Widera, M., Grikscheit, K., Toptan, T. \& Schenk, B. Reduced neutralization of SARS-CoV-2 Omicron variant by vaccine sera and monoclonal antibodies. MedRxiv (2021).

7. Wang, Y. et al. The significant immune escape of pseudotyped SARS-CoV-2 variant Omicron. Emerg. Microbes Infect. 11, 1-5 (2022).

8. Uriu, K. et al. Neutralization of the SARS-CoV-2 Mu Variant by Convalescent and Vaccine Serum. New England Journal of Medicine vol. 385 2397-2399 (2021).

9. Yu, X. et al. Enhanced neutralization against SARS-CoV-2 by vaccine booster exhibits reduction of Omicron variant. bioRxiv (2021) doi:10.1101/2021.12.17.21267961.

10. Bowen, J. E. et al. SARS-CoV-2 spike conformation determines plasma neutralizing activity. bioRxiv 2021.12.19.473391 (2021) doi:10.1101/2021.12.19.473391.

11. Rössler, A., Riepler, L., Bante, D., von Laer, D. \& Kimpel, J. SARS-CoV-2 B.1.1.529 variant (Omicron) evades neutralization by sera from vaccinated and convalescent individuals. doi:10.1101/2021.12.08.21267491. 
12. Cameroni, E. et al. Broadly neutralizing antibodies overcome SARS-CoV-2 Omicron antigenic shift. bioRxiv (2021) doi:10.1101/2021.12.12.472269.

13. Meng, B. et al. SARS-CoV-2 Omicron spike mediated immune escape, infectivity and cellcell fusion. (2021).

14. Cong, Z. et al. Neutralization and Stability of SARS-CoV-2 Omicron Variant. doi:10.1101/2021.12.16.472934.

15. Pfizer and BioNTech Provide Update on Omicron Variant. https://www.pfizer.com/news/press-release/press-release-detail/pfizer-and-biontechprovide-update-omicron-variant.

16. Schmidt, F. et al. Plasma neutralization properties of the SARS-CoV-2 Omicron variant. Google Docs https://drive.google.com/file/d/1zjJWsybGaa3egiyn5nQqTzBtl0kmvMUu/view (2021).

17. Neutralization Data Posted on Twitter by Joe Scholar. Twitter https://twitter.com/JScholar/status/1470110894856286216 (2021).

18. HKUMed-CU Medicine joint study finds COVID-19 variant Omicron significantly reduces virus neutralisation ability of BioNTech vaccine.

http://www.med.hku.hk/en/news/press/20211212-omicron-avoids-killing-by-blood-serum.

19. Garcia-Beltran, W. F. et al. mRNA-based COVID-19 vaccine boosters induce neutralizing immunity against SARS-CoV-2 Omicron variant. medRxiv (2021)

doi:10.1101/2021.12.14.21267755.

20. Gruell, H., Vanshylla, K., Tober-Lau, P. \& Hillus, D. mRNA booster immunization elicits potent neutralizing serum activity against the SARS-CoV-2 Omicron variant. medRxiv (2021).

21. Hoffmann, M., Krüger, N., Schulz, S. \& Cossmann, A. The Omicron variant is highly resistant against antibody-mediated neutralization-implications for control of the COVID-19 
pandemic. bioRxiv (2021).

22. Doria-Rose, N. A. et al. Booster of mRNA-1273 Vaccine Reduces SARS-CoV-2 Omicron Escape from Neutralizing Antibodies. medRxiv (2021) doi:10.1101/2021.12.15.21267805.

23. Liu, L. et al. Striking Antibody Evasion Manifested by the Omicron Variant of SARS-CoV-2. bioRxiv (2021).

24. Planas, D., Saunders, N., Maes, P. \& Benhassine, F. G. Considerable escape of SARSCoV-2 variant Omicron to antibody neutralization. bioRxiv (2021).

25. Dejnirattisai, W., Shaw, R. H., Supasa, P., Liu, C. \& Stuart, A. S. V. Reduced neutralisation of SARS-COV-2 Omicron-B. 1.1. 529 variant by post-immunisation serum. medRxiv (2021).

26. Zhao, X. et al. Reduced sera neutralization to Omicron SARS-CoV-2 by both inactivated and protein subunit vaccines and the convalescents. bioRxiv 2021.12.16.472391 (2021) doi:10.1101/2021.12.16.472391.

27. Feng, S. et al. Correlates of protection against symptomatic and asymptomatic SARS-CoV2 infection. Nat. Med. 27, 2032-2040 (2021).

28. Gilbert, P. B. et al. Immune Correlates Analysis of the mRNA-1273 COVID-19 Vaccine Efficacy Trial. medRxiv (2021) doi:10.1101/2021.08.09.21261290. 
Table 1: List of considered studies.

\begin{tabular}{|c|c|c|c|c|}
\hline Study & Date of appearance & Assay Type & Cell Type & R346K \\
\hline Sigal $^{4}$ & $2021.12 .6 \& 15$ & Live-virus & H1299 ACE2 & Yes \\
\hline Sheward ${ }^{5}$ & 2021.12 .7 & Lentiviral Pseudotype & HEK293T ACE2 & No \\
\hline Pfizer/BioNTech ${ }^{15}$ & 2021.12 .8 & Pseudotype & Unknown & NA \\
\hline Ciesek $^{6}$ & 2021.12 .8 & Live-virus & Caco-2 & No \\
\hline Kimpel $^{11}$ & 2021.12 .8 & Live-virus & Unknown & No \\
\hline Schmidt ${ }^{16}$ & 2021.12.12 & HIV-1 Pseudotype & HT1080 ACE2 & No \\
\hline Israel $\mathbf{M o H}^{17}$ & 2021.12.12 & Live-virus & Unknown & NA \\
\hline Zhang $^{7}$ & 2021.12 .10 & Pseudotype & Huh 7 & No \\
\hline HKU18 & 2021.12 .12 & Live-virus & Unknown & NA \\
\hline Balazs $^{19}$ & 2021.12 .14 & Lentiviral Pseudotype & HEK293T ACE2 & No \\
\hline Gruell $^{20}$ & 2021.12 .14 & Lentiviral Pseudotype & HEK293T ACE2 & No \\
\hline Corti $^{12}$ & 2021.12 .14 & VSV Pseudotype & VeroE6 & No \\
\hline Poehlmann ${ }^{21}$ & 2021.12 .13 & VSV Pseudotype & Vero Cells & No \\
\hline Montefiori/Doria-Rose ${ }^{22}$ & 2021.12 .15 & Lentiviral Pseudotype & Unknown & No \\
\hline $\mathrm{Ho}^{23}$ & 2021.12 .15 & Pseudovirus & VeroE6 & Yes \\
\hline Schwartz ${ }^{24}$ & 2021.12 .14 & Live-virus & S-Fuse cells & NA \\
\hline Gupta $^{13}$ & 2021.12 .20 & Pseudovirus & 293T TMPRSS2* & NA \\
\hline Snape $^{25}$ & 2021.12.11 & Live-virus & Vero Cells & NA \\
\hline Liu $^{14}$ & 2021.12 .20 & Lentiviral Pseudotype & HEK293T ACE2 & NA \\
\hline Krammer ${ }^{8}$ & 2021.12 .20 & Live-virus & VeroE6 TMPRSS2 & NA \\
\hline Chen $^{9}$ & 2021-12-22 & Pseudovirus & Unknown & NA \\
\hline $\mathrm{Gao}^{26}$ & $2021-12-22$ & Pseudovirus & Unknown & NA \\
\hline Veesler ${ }^{10}$ & $2021-12-22$ & VSV Pseudotype & VeroE6 TMPRSS2 & NA \\
\hline
\end{tabular}

*293T TMPRSS2 ACE2 transfected. NA in Column R346K was used when no information on this substitution was available. Supplementary Tables 1-4 have further details on these studies.

\section{Methods}

\section{Data collection}

Omicron neutralization data from publicly available preprints, reports or tweets were collected and categorized according to assay type, vaccine and convalescent sera tested, and the presence of the R346K substitution in the spike in addition to the common set of Omicron spike substitutions. In most cases, datasets are named after the corresponding author. A full list of all studies considered is shown in Table 1, detailed metadata in Supplementary Tables 1-4. 


\section{Geometric Mean Titer and fold drop calculation}

We used numerical data on geometric mean titers (GMT) and Omicron titer fold drops to a reference antigen as stated in each preprint. In case of missing GMT data, GMTs were either directly extracted from the manuscripts' figures using Webplotdigitizer ${ }^{2}$ or individual data points were extracted by the same method and GMTs subsequently calculated with the meantiter $R$ package $^{3}$ (method $=$ "truncated_normal", dilution_stepsize $=0$ ), which performs a Bayesian statistics analysis to correctly handle thresholded values. Thresholded titers for individual data were set to "<Limit of Detection (LOD)" prior to GMT calculation via the meantiters package. In case of thresholded GMTs directly available or extracted from the manuscript, we set the GMT estimates to LOD/2. When data points needed to be extracted from figures, individual measurements were often overlapping and difficult to distinguish. Hence, in some cases the sample number given in the manuscript differs from the number of data points used to calculate the GMT in this analysis. If numerical data on fold drops but not GMTs were available, we used the fold drops as given in the manuscript and determined GMTs as described above. Otherwise fold drops were calculated by dividing the reference antigen GMT by the Omicron GMT. Omicron GMTs were obtained by applying the fold drop from to the reference antigen GMT. GMTs per serum group were calculated using the meantiter $\mathrm{R}$ package ${ }^{3}$ with the same parameters as before.

Webplotdigitizer $^{2}$ was used for the following studies: GMTs for Sigal ${ }^{4}{ }^{*}$ Pfizer and Infection(Inf)+Pfizer sera, Sheward ${ }^{5}$, Ciesek $^{6}$, Zhang $^{7}$ (subset), Krammer ${ }^{8}$, Chen $^{9}$ and Veesler ${ }^{10}$ were obtained by Webplotdigitizer. GMTs and fold changes were obtained by Webplotdigitzer for Kimpel ${ }^{11}$, Corti ${ }^{12}$ (subset), Gupta ${ }^{13}$ and Liu ${ }^{14}$. The data for Pfizer/BioNTech ${ }^{15}$, Schmidt ${ }^{16}$, Israel $\mathrm{MoH}^{17}, \mathrm{HKU}^{18}$, Balazs ${ }^{19}$, Gruell ${ }^{20}$, Poehlmann ${ }^{21}$, Montefiori/Doria-Rose ${ }^{22}, \mathrm{Ho}^{23}$, Schwartz ${ }^{24}$, Snape ${ }^{25}, \mathrm{GaO}^{26}$ were directly obtained from the respective manuscripts or reports. 


\section{Dataset availability}

The aggregate dataset is available as a publicly accessible google sheets document ${ }^{1}$.

Acknowledgements: Thanks and kudos, to the laboratories listed above that have rapidly generated data and put it into the public domain. We thank Poppy Roth for technical assistance. Funding: This work was funded by the NIH Centers of Excellence for Influenza Research and Surveillance (CEIRS, contract \# HHSN272201400008C) and Centers of Excellence for Influenza Research and Response (CEIRR, contract \#75N93021C00014).

Author contributions: B. Mühlemann contributed information on recently published datasets and reviewing the manuscript. S.H. Wilks contributed the initial fold drop forest plot.

The authors declare no competing interests.

Supplementary Information is available for this paper.

Correspondence and requests for materials should be addressed to Derek J. Smith (djs200@cam.ac.uk) 


\section{Extended Data} (which was not certified by peer review) is the author/funder. All rights reserved. No reuse allowed without permission.
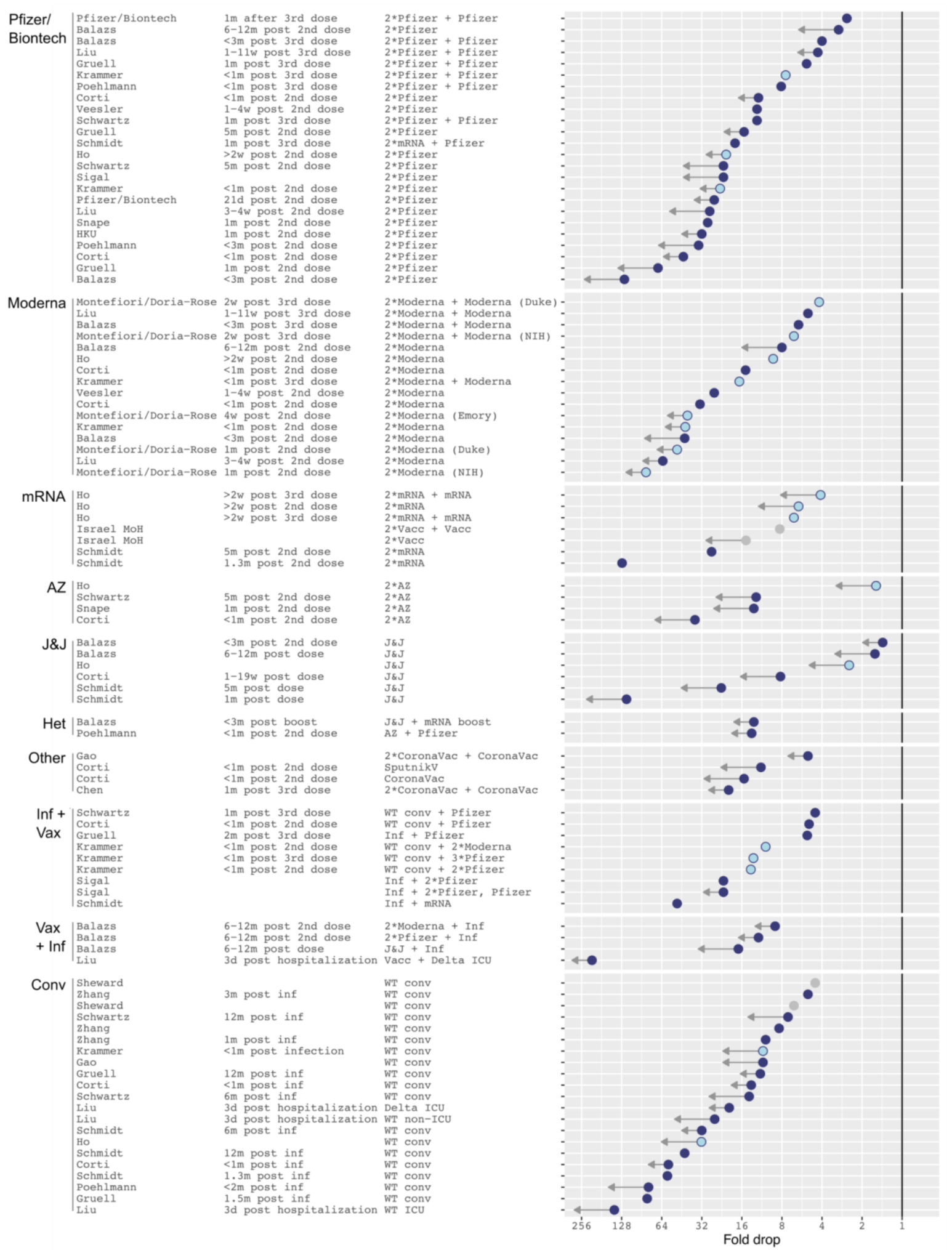

Extended Data Figure 1: Omicron fold drops grouped by vaccine type relative to wild type. Data was grouped by vaccine type and infection history (mRNA: unspecified mRNA vaccine, AZ: AstraZeneca, J\&J: Johnson \& Johnson, Het: Heterologous vaccination, Inf + Vax: infection then vaccinations, Vax + Inf: vaccination then infection, Conv: convalescent). The solid line marks no fold change. Arrows indicate uncertainties in the point estimate. A short arrow marks measurements with less than half of Omicron titers below the assay's limit of detection (LOD), or conversely reference antigen titers at or higher than the LOD. Long arrows mark measurements with more than approximately $80 \%$ of Omicron titers below the LOD. Light blue dots show NIH SAVE laboratories, gray dots mark data points for which the reference antigen was not stated in the manuscript and is here assumed to be Wu-1. 
bioRxiv preprint doi: https://doi.org/10.1101/2021.12.31.474032; this version posted January 7, 2022. The copyright holder for this preprint (which was not certified by peer review) is the author/funder. All rights reserved. No reuse allowed without permission.

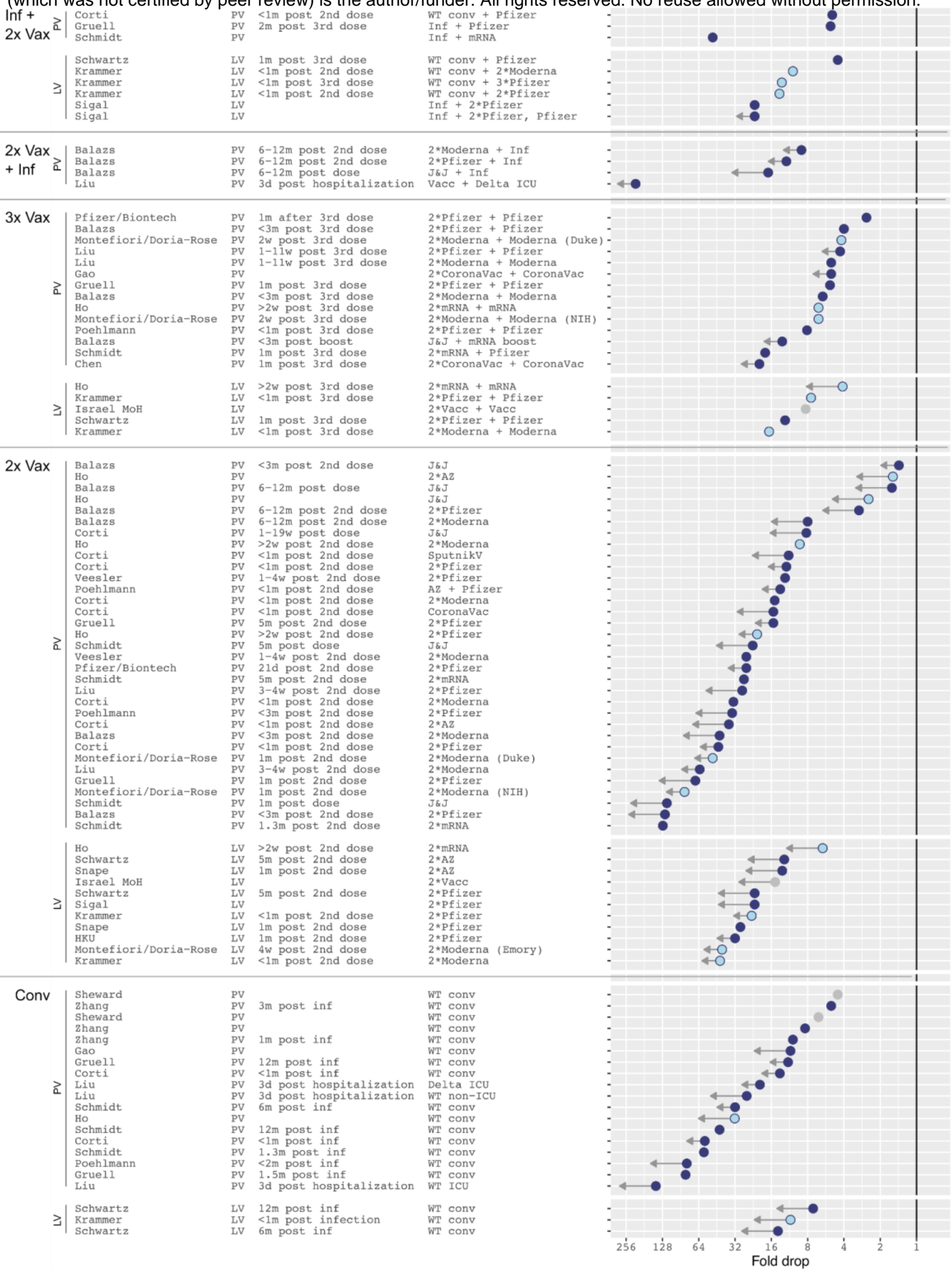

Extended Data Figure 2: Omicron fold drops grouped by serum group and assay relative to wild type. Same as Extended Data Figure 1, but datasets are grouped by serum group and within the serum groups subgrouped by assay type (LV: Live-virus, PV: Pseudovirus). 
bioRxiv preprint doi: https://doi.org/10.1101/2021.12.31.474032; this version posted January 7, 2022. The copyright holder for this preprint (which was not certified by peer review) is the author/funder. All rights reserved. No reuse allowed without permission.

\begin{tabular}{|c|c|c|c|c|c|c|}
\hline \multirow[t]{5}{*}{$\begin{array}{l}\text { Inf }+ \\
2 x \text { Vax }\end{array}$} & $\mid \begin{array}{l}\text { Corti } \\
\text { Krammer } \\
\text { Krammer } \\
\text { Krammer }\end{array}$ & $\begin{array}{l}\text { PV } \\
\text { LV } \\
\text { LV } \\
\text { LV }\end{array}$ & $\begin{array}{l}\text { (VeroE6-TMPRSS2) } \\
\text { (VeroE6-TMPRSS2) } \\
\text { (VeroE6-TMPRSS2) } \\
\text { (VeroE6-TMPRSS2) }\end{array}$ & $\begin{array}{l}<1 \mathrm{~m} \text { post } 2 \text { nd dose } \\
<1 \mathrm{~m} \text { post } 2 \text { nd dose } \\
\text { <1m post } 3 \mathrm{rd} \text { dose } \\
<1 \mathrm{~m} \text { post } 2 \text { nd dose }\end{array}$ & $\begin{array}{l}\text { WT conv + Pfizer } \\
\text { WT conv + 2*Moderna } \\
\text { WT conv }+3 * \text { Pfizer } \\
\text { WT conv }+2 * \text { Pfizer }\end{array}$ & $8^{\circ}$ \\
\hline & | Gruell & PV & (HEK293T-ACE2) & $2 \mathrm{~m}$ post $3 \mathrm{rd}$ dose & Inf + Pfizer & - \\
\hline & $\mid \begin{array}{l}\text { Sigal } \\
\text { sigal }\end{array}$ & $\begin{array}{l}\text { LV } \\
\text { LV }\end{array}$ & $\begin{array}{l}\text { (H1299-ACE2) } \\
\text { (H1299-ACE2) }\end{array}$ & & $\begin{array}{l}\text { Inf }+2 * \text { pfizer } \\
\text { Inf }+2 * \text { Pfizer, pfizer }\end{array}$ & 8 \\
\hline & I Schmidt & PV & (HT1080/ACE2) & & Inf + mRNA & $\bullet$ \\
\hline & I Schwartz & LV & (S-Fuse) & 1m post 3 rd dose & WT conv + Pfizer & $\bullet$ \\
\hline $\begin{array}{l}2 x \operatorname{Vax} \\
+\operatorname{Inf}\end{array}$ & $\mid \begin{array}{l}\text { Balazs } \\
\text { Balazs } \\
\text { Balazs } \\
\text { Liu }\end{array}$ & $\begin{array}{l}\text { PV } \\
\text { PV } \\
\text { PV } \\
\text { PV }\end{array}$ & $\begin{array}{l}\text { (HEK293T-ACE2) } \\
\text { (HEK293T-ACE2) } \\
\text { (HEK293T-ACE2) } \\
\text { (HEK293T-ACE2) }\end{array}$ & $\begin{array}{l}6-12 \mathrm{~m} \text { post } 2 \text { nd dose } \\
6-12 \mathrm{~m} \text { post } 2 \text { nd dose } \\
6-12 \mathrm{~m} \text { post dose } \\
\text { 3d post hospitalization }\end{array}$ & $\begin{array}{l}2 * \text { Moderna }+ \text { Inf } \\
2 * \text { Pfizer }+ \text { Inf } \\
\text { J\&J + Inf } \\
\text { Vacc + Delta ICU }\end{array}$ & $\begin{array}{l}- \\
-40\end{array}$ \\
\hline \multirow[t]{7}{*}{$3 x \operatorname{Vax}$} & | Poehlmann & PV & (Vero) & $<1 \mathrm{~m}$ post $3 \mathrm{rd}$ dose & $2 *$ pfizer + Pfizer & $\bullet$ \\
\hline & | Ho & PV & (VeroE6) & $>2 \mathrm{w}$ post $3 \mathrm{rd}$ dose & $2 *$ mRNA + mRNA & 0 \\
\hline & $\mid \begin{array}{l}\text { Ho } \\
\text { Krammer } \\
\text { Krammer }\end{array}$ & $\begin{array}{l}\text { LV } \\
\text { LV } \\
\text { LV }\end{array}$ & $\begin{array}{l}\text { (VeroE6-TMPRSS2) } \\
\text { (VeroE6-TMPRSS2) } \\
\text { (VeroE6-TMPRSS2) }\end{array}$ & $\begin{array}{l}>2 \mathrm{w} \text { post } 3 \mathrm{rd} \text { dose } \\
<1 \mathrm{~m} \text { post } 3 \mathrm{rd} \text { dose } \\
<1 \mathrm{~m} \text { post } 3 \mathrm{rd} \text { dose }\end{array}$ & $\begin{array}{l}2 * \text { mRNA }+ \text { mRNA } \\
2 * \text { Pfizer }+ \text { Pfizer } \\
2 * \text { Moderna }+ \text { Moderna }\end{array}$ & 40 \\
\hline & $\mid \begin{array}{l}\text { Balazs } \\
\text { Liu } \\
\text { Liu } \\
\text { Gruel1 } \\
\text { Balazs } \\
\text { Balazs }\end{array}$ & $\begin{array}{l}\text { PV } \\
\text { PV } \\
\text { PV } \\
\text { PV } \\
\text { PV } \\
\text { PV }\end{array}$ & $\begin{array}{l}\text { (HEK293T-ACE2) } \\
\text { (HEK293T-ACE2) } \\
\text { (HEK293T-ACE2) } \\
\text { (HEK293T-ACE2) } \\
\text { (HEK293T-ACE2) } \\
\text { (HEK293T-ACE2) }\end{array}$ & $\begin{array}{l}<3 \mathrm{~m} \text { post } 3 \mathrm{rd} \text { dose } \\
1-11 \mathrm{w} \text { post } 3 \mathrm{rd} \text { dose } \\
1-11 \mathrm{w} \text { post } 3 \mathrm{rd} \text { dose } \\
1 \mathrm{~m} \text { post } 3 \mathrm{rd} \text { dose } \\
<3 \mathrm{~m} \text { post } 3 \mathrm{rd} \text { dose } \\
<3 \mathrm{~m} \text { post boost }\end{array}$ & $\begin{array}{l}\text { 2*pfizer + Pfizer } \\
\text { 2*pfizer + Pfizer } \\
\text { 2*Moderna + Moderna } \\
\text { 2*Pfizer + pfizer } \\
\text { 2*Moderna + Moderna } \\
\text { J\&J + mRNA boost }\end{array}$ & 8 \\
\hline & I Schmidt & PV & (HT1080/ACE2) & Im post $3 \mathrm{rd}$ dose & $2 *$ mRNA + Pfizer & $\cdot$ \\
\hline & | Schwartz & LV & (S-Fuse) & Im post $3 \mathrm{rd}$ dose & $2 *$ pfizer + Pfizer & - \\
\hline & \begin{tabular}{|l} 
Pfizer/Biontech \\
Montefiori/Doria-Rose \\
Gao \\
Montefiori/Doria-Rose \\
Israel MoH \\
Chen
\end{tabular} & $\begin{array}{l}\text { PV } \\
\text { PV } \\
\text { PV } \\
\text { PV } \\
\text { LV } \\
\text { PV }\end{array}$ & $\begin{array}{l}\text { (Unknown) } \\
\text { (Unknown) } \\
\text { (Unknown) } \\
\text { (Unknown) } \\
\text { (Unknown) } \\
\text { (Unknown) }\end{array}$ & $\begin{array}{l}1 \mathrm{~m} \text { after } 3 \mathrm{rd} \text { dose } \\
2 \mathrm{w} \text { post } 3 \mathrm{rd} \text { dose } \\
2 \mathrm{w} \text { post } 3 \mathrm{rd} \text { dose } \\
1 \mathrm{~m} \text { post } 3 \mathrm{rd} \text { dose }\end{array}$ & $\begin{array}{l}\text { 2*pfizer + Pfizer } \\
\text { 2*Moderna }+ \text { Moderna (Duke) } \\
\text { 2*CoronaVac + CoronaVac } \\
\text { 2*Moderna + Moderna (NIH) } \\
\text { 2*Vacc + Vacc } \\
\text { 2*CoronaVac + CoronaVac }\end{array}$ & $0_{0}^{\circ}$ \\
\hline \multirow[t]{8}{*}{$2 x \operatorname{Vax}$} & $\mid \begin{array}{l}\text { Snape } \\
\text { Poeh1mann } \\
\text { Snape } \\
\text { Poehlmann }\end{array}$ & $\begin{array}{l}\text { LV } \\
\text { PV } \\
\text { LV } \\
\text { PV }\end{array}$ & $\begin{array}{l}\text { (Vero) } \\
\text { (Vero) } \\
\text { (Vero) } \\
\text { (Vero) }\end{array}$ & $\begin{array}{l}1 \mathrm{~m} \text { post } 2 \text { nd dose } \\
<1 \mathrm{~m} \text { post } 2 \text { nd dose } \\
1 \mathrm{~m} \text { post } 2 \text { nd dose } \\
<3 \mathrm{~m} \text { post } 2 \text { nd dose }\end{array}$ & $\begin{array}{l}2 * A Z \\
A Z+P f i z e r \\
2 * \text { Pfizer } \\
2 * P f i z e r\end{array}$ & $\begin{array}{ll}: & \\
5 & 4\end{array}$ \\
\hline & $\begin{array}{l}\text { Ho } \\
\text { Ho } \\
\text { Corti } \\
\text { Ho } \\
\text { Corti } \\
\text { Corti } \\
\text { Ho } \\
\text { Corti } \\
\text { Corti } \\
\text { Corti }\end{array}$ & $\begin{array}{l}\text { PV } \\
\text { PV } \\
\text { PV } \\
\text { PV } \\
\text { PV } \\
\text { PV } \\
\text { PV } \\
\text { PV } \\
\text { PV } \\
\text { PV }\end{array}$ & $\begin{array}{l}\text { (VeroE6) } \\
\text { (VeroE6) } \\
\text { (VeroE6) } \\
\text { (VeroE6) } \\
\text { (VeroE6) } \\
\text { (VeroE6) } \\
\text { (VeroE6) } \\
\text { (VeroE6) } \\
\text { (VeroE6) } \\
\text { (VeroE6) }\end{array}$ & $\begin{array}{l}\text { 1-19w post dose } \\
>2 \mathrm{w} \text { post } 2 \text { nd dose } \\
<1 \mathrm{~m} \text { post 2nd dose } \\
<1 \mathrm{~m} \text { post 2nd dose } \\
>2 \mathrm{w} \text { post } 2 \text { nd dose } \\
<1 \mathrm{~m} \text { post } 2 \text { nd dose } \\
<1 \mathrm{~m} \text { post } 2 \text { nd dose } \\
<1 \mathrm{~m} \text { post 2nd dose }\end{array}$ & $\begin{array}{l}2 * \mathrm{AZ} \\
\text { J\&J } \\
\text { J6J } \\
2 * \text { Moderna } \\
\text { SputnikV } \\
\text { CoronaVac } \\
2 * \text { Pfizer } \\
2 * \text { Moderna } \\
2 * \text { Az } \\
2 * \text { Pfizer }\end{array}$ & $\begin{array}{ll}: & : \\
\vdots & 4_{0}^{40}\end{array}$ \\
\hline & $\mid \begin{array}{l}\text { Ho } \\
\text { Corti } \\
\text { Veesler } \\
\text { Corti } \\
\text { Krammer } \\
\text { Veesler } \\
\text { Krammer }\end{array}$ & $\begin{array}{l}\text { LV } \\
\text { PV } \\
\text { PV } \\
\text { PV } \\
\text { LV } \\
\text { PV } \\
\text { LV }\end{array}$ & $\begin{array}{l}\text { (VeroE6-TMPRSS2) } \\
\text { (VeroE6-TMPRSS2) } \\
\text { (VeroE6-TMPRSS2) } \\
\text { (VeroE6-TMPRSS2) } \\
\text { (VeroE6-TMPRSS2) } \\
\text { (VeroE6-TMPRSS2) } \\
\text { (VeroE6-TMPRSS2) }\end{array}$ & $\begin{array}{l}>2 \mathrm{w} \text { post } 2 \text { nd dose } \\
<1 \mathrm{~m} \text { post } 2 \text { nd dose } \\
1-4 \mathrm{w} \text { post } 2 \text { nd dose } \\
<1 \mathrm{~m} \text { post } 2 \text { nd dose } \\
<1 \mathrm{~m} \text { post } 2 \text { nd dose } \\
1-4 \mathrm{w} \text { post } 2 \text { nd dose } \\
<1 \mathrm{~m} \text { post } 2 \text { nd dose }\end{array}$ & $\begin{array}{l}2 * \text { mRNA } \\
2 * \text { pfizer } \\
2 * \text { pfizer } \\
2 * \text { Moderna } \\
2 * \text { pfizer } \\
2 * \text { Moderna } \\
\text { 2*Moderna }\end{array}$ & \begin{tabular}{l|l}
$:$ & $\mid 1$ \\
$\vdots$ & 1 \\
$\vdots$ & 40
\end{tabular} \\
\hline & \begin{tabular}{|l} 
Balazs \\
Balazs \\
Balazs \\
Balazs \\
Gruell \\
Liu \\
Balazs \\
Liu \\
Grue11 \\
Balazs
\end{tabular} & $\begin{array}{l}\text { PV } \\
\text { PV } \\
\text { PV } \\
\text { PV } \\
\text { PV } \\
\text { PV } \\
\text { PV } \\
\text { PV } \\
\text { PV } \\
\text { PV }\end{array}$ & $\begin{array}{l}\text { (HEK293T-ACE2) } \\
\text { (HEK293T-ACE2) } \\
\text { (HEK293T-ACE2) } \\
\text { (HEK293T-ACE2) } \\
\text { (HEK293T-ACE2) } \\
\text { (HEK293T-ACE2) } \\
\text { (HEK293T-ACE2) } \\
\text { (HEK293T-ACE2) } \\
\text { (HEK293T-ACE2) } \\
\text { (HEK293T-ACE2) }\end{array}$ & $\begin{array}{l}<3 \mathrm{~m} \text { post } 2 \text { nd dose } \\
6-12 \mathrm{~m} \text { post dose } \\
6-12 \mathrm{~m} \text { post } 2 \text { nd dose } \\
6-12 \mathrm{~m} \text { post } 2 \text { nd dose } \\
5 \mathrm{~m} \text { post } 2 \text { nd dose } \\
3-4 \mathrm{w} \text { post } 2 \text { nd dose } \\
<3 \mathrm{~m} \text { post } 2 \text { nd dose } \\
3-4 \mathrm{w} \text { post } 2 \text { nd dose } \\
1 \mathrm{~m} \text { post } 2 \mathrm{nd} \text { dose } \\
<3 \mathrm{~m} \text { post } 2 \text { nd dose }\end{array}$ & $\begin{array}{l}\text { J\&J } \\
\text { JkJ } \\
2 * \text { Pfizer } \\
2 * \text { Moderna } \\
\text { 2*Pfizer } \\
\text { 2*Pfizer } \\
\text { 2*Moderna } \\
\text { 2*Moderna } \\
\text { 2*Pfizer } \\
\text { 2*Pfizer }\end{array}$ & $\begin{array}{l}\vdots \\
\vdots \\
\vdots\end{array}$ \\
\hline & | Sigal & LV & (H1299-ACE2) & & $2 *$ Pfizer & $-\quad \quad \leftrightarrow \bullet$ \\
\hline & $\mid \begin{array}{l}\text { Schmidt } \\
\text { Schmidt } \\
\text { Schmidt } \\
\text { Schmidt }\end{array}$ & $\begin{array}{l}\text { PV } \\
\text { PV } \\
\text { PV } \\
\text { PV }\end{array}$ & $\begin{array}{l}\text { (HT1080/ACE2) } \\
\text { (HT1080/ACE2) } \\
\text { (HT1080/ACE2) } \\
\text { (HT1080/ACE2) }\end{array}$ & $\begin{array}{l}5 \mathrm{~m} \text { post dose } \\
5 \mathrm{~m} \text { post } 2 \mathrm{nd} \text { dose } \\
\text { 1m post dose } \\
1.3 \mathrm{~m} \text { post } 2 \text { nd dose }\end{array}$ & $\begin{array}{l}\mathrm{J} \leftarrow \mathrm{J} \\
2 * \mathrm{mRNA} \\
\mathrm{J} \& \mathrm{~J} \\
2 * \mathrm{mRNA}\end{array}$ & $: 48$ \\
\hline & $\mid \begin{array}{l}\text { Schwartz } \\
\text { Schwartz }\end{array}$ & $\begin{array}{l}\mathrm{LV} \\
\mathrm{LV}\end{array}$ & $\begin{array}{l}\text { (S-Fuse) } \\
\text { (S-Fuse) }\end{array}$ & $\begin{array}{l}5 \mathrm{~m} \text { post } 2 \text { nd dose } \\
5 \mathrm{~m} \text { post } 2 \text { nd dose }\end{array}$ & $\begin{array}{l}2 * \mathrm{AZ} \\
2 * \text { Pfizer }\end{array}$ & $: \quad 4 \bullet$ \\
\hline & \begin{tabular}{|l} 
Israel MoH \\
Pfizer/Biontech \\
HKU \\
Montefiori/Doria-Rose \\
Montefiori/Doria-Rose \\
Montefiori/Doria-Rose
\end{tabular} & $\begin{array}{l}\mathrm{LV} \\
\mathrm{PV} \\
\mathrm{LV} \\
\mathrm{LV} \\
\mathrm{PV} \\
\mathrm{PV}\end{array}$ & $\begin{array}{l}\text { (Unknown) } \\
\text { (Unknown) } \\
\text { (Unknown) } \\
\text { (Unknown) } \\
\text { (Unknown) } \\
\text { (Unknown) }\end{array}$ & $\begin{array}{l}\text { 21d post } 2 \text { nd dose } \\
\text { 1m post } 2 \text { nd dose } \\
4 \mathrm{w} \text { post 2nd dose } \\
\text { 1m post 2nd dose } \\
\text { 1m post 2nd dose }\end{array}$ & $\begin{array}{l}\text { 2*Vacc } \\
\text { 2*:*fizer } \\
\text { 2*Pfizer } \\
\text { 2**aderna (Emory) } \\
\text { 2*Moderna (Duke) } \\
\text { 2*Moderna (NIH) }\end{array}$ & $: \quad 40^{40}$ \\
\hline \multirow[t]{8}{*}{ Conv } & I Poeh1mann & PV & (Vero) & $<2 \mathrm{~m}$ post inf & WT conv & -40 \\
\hline & $\left.\right|_{\text {Ho }} ^{\text {Corti }}$ & $\begin{array}{l}\mathrm{PV} \\
\mathrm{PV}\end{array}$ & $\begin{array}{l}\text { (VeroE6) } \\
\text { (VeroE6) }\end{array}$ & $<1 \mathrm{~m}$ post inf & $\begin{array}{l}\text { WT conv } \\
\text { WT conv }\end{array}$ & $: \quad 40<$ \\
\hline & $\mid \begin{array}{l}\text { Krammer } \\
\text { Corti }\end{array}$ & $\begin{array}{l}\mathrm{LV} \\
\mathrm{PV}\end{array}$ & $\begin{array}{l}\text { (VeroE6-TMPRSS2) } \\
\text { (VeroE6-TMPRSS2) }\end{array}$ & $\begin{array}{l}<1 \mathrm{~m} \text { post infection } \\
<1 \mathrm{~m} \text { post inf }\end{array}$ & $\begin{array}{l}\text { WT conv } \\
\text { WT conv }\end{array}$ & $: \quad 40$ \\
\hline & \begin{tabular}{|l} 
Sheward \\
Sheward \\
Gruell \\
Liu \\
Liu \\
Gruell \\
Liu
\end{tabular} & $\begin{array}{l}\text { PV } \\
\text { PV } \\
\text { PV } \\
\text { PV } \\
\text { PV } \\
\text { PV } \\
\text { PV }\end{array}$ & $\begin{array}{l}\text { (HEK293T-ACE2) } \\
\text { (HEK293T-ACE2) } \\
\text { (HEK293T-ACE2) } \\
\text { (HEK293T-ACE2) } \\
\text { (HEK293T-ACE2) } \\
\text { (HEK293T-ACE2) } \\
\text { (HEK293T-ACE2) }\end{array}$ & $\begin{array}{l}\text { 12m post inf } \\
3 \mathrm{~d} \text { post hospitalization } \\
3 \mathrm{~d} \text { post hospitalization } \\
1.5 \mathrm{~m} \text { post inf } \\
3 \mathrm{~d} \text { post hospitalization }\end{array}$ & $\begin{array}{l}\text { WT conv } \\
\text { WT conv } \\
\text { WT conv } \\
\text { Delta ICU } \\
\text { WT non-ICU } \\
\text { WT conv } \\
\text { WT ICU }\end{array}$ & $\sum^{\vdots} 0^{4} 0^{40}$ \\
\hline & $\mid \begin{array}{l}\text { Schmidt } \\
\text { Schmidt } \\
\text { Schmidt }\end{array}$ & $\begin{array}{l}\text { PV } \\
\text { PV } \\
\text { PV }\end{array}$ & $\begin{array}{l}\text { (HT1080/ACE2) } \\
\text { (HT1080/ACE2) } \\
\text { (HT1080/ACE2) }\end{array}$ & $\begin{array}{l}6 \mathrm{~m} \text { post inf } \\
12 \mathrm{~m} \text { post inf } \\
1.3 \mathrm{~m} \text { post inf }\end{array}$ & $\begin{array}{l}\text { WT conv } \\
\text { WT conv } \\
\text { WT conv }\end{array}$ & $: \quad 0^{\circ}$ \\
\hline & $\mid \begin{array}{l}\text { Schwartz } \\
\text { Schwartz }\end{array}$ & $\begin{array}{l}\text { LV } \\
\text { LV }\end{array}$ & $\begin{array}{l}\text { (S-Fuse) } \\
\text { (S-Fuse) }\end{array}$ & $\begin{array}{l}12 \mathrm{~m} \text { post inf } \\
6 \mathrm{~m} \text { post inf }\end{array}$ & $\begin{array}{l}\text { WT conv } \\
\text { WT conv }\end{array}$ & $: \quad \leftrightarrow \bullet^{4}$ \\
\hline & $\left|\begin{array}{l}\text { Zhang } \\
\text { Zhang } \\
\text { zhang }\end{array}\right|$ & $\begin{array}{l}\mathrm{PV} \\
\mathrm{PV} \\
\mathrm{PV}\end{array}$ & $\begin{array}{l}\text { (Huh 7) } \\
\text { (Huh 7) } \\
\text { (Huh 7) }\end{array}$ & $\begin{array}{l}3 \mathrm{~m} \text { post inf } \\
1 \mathrm{~m} \text { post inf }\end{array}$ & $\begin{array}{l}\text { WT conv } \\
\text { WT conv } \\
\text { WT conv }\end{array}$ & $\vdots$ \\
\hline & I Gao & PV & (Unknown) & & WT conv &  \\
\hline
\end{tabular}

Extended Data Figure 3: Omicron fold drops grouped by serum group and cell type relative to wild type. Same as Extended Data Figure 1, but datasets are grouped by serum group and within the serum groups subgrouped by cell type (LV: Live-virus, PV: Pseudovirus). 
bioRxiv preprint doi: https://doi.org/10.1101/2021.12.31.474032; this version posted January 7, 2022. The copyright holder for this preprint (which was not certified by peer review) is the author/funder. All rights reserved. No reuse allowed without permission.

A

2x Vax $\mid \begin{aligned} & \text { Kimpel } \\ & \text { Kimpel } \\ & \text { Kimpel } \\ & \text { Kimpel }\end{aligned}$

Conv $\mid \begin{aligned} & \text { Kimpel } \\ & \text { Kimpel } \\ & \text { Kimpel }\end{aligned}$

\section{B}

\begin{tabular}{c|l} 
2x Vax & $\begin{array}{l}\text { Kimpel } \\
\text { Kimpel } \\
\text { Kimpel } \\
\text { Kimpel }\end{array}$ \\
Conv & Kimpel
\end{tabular}

Conv $\mid \begin{aligned} & \text { Kimpel } \\ & \text { Kimpel } \\ & \text { Kimpel }\end{aligned}$

\section{C}

Inf $+2 x$ Vax $\mid$ Kimpel

$2 x$ Vax + Inf $\mid \begin{aligned} & \text { Kimpel } \\ & \text { Ciesek }\end{aligned}$

$3 x$ Vax $\mid \begin{aligned} & \text { Gupta } \\ & \text { Gupta } \\ & \text { Ciesek } \\ & \text { Ciesek } \\ & \text { Ciesek } \\ & \text { Ciesek }\end{aligned}$

$2 x$ Vax $\mid \begin{aligned} & \text { Gupta } \\ & \text { Gupta }\end{aligned}$

Gupta
Gupta
Ciesek

Ciesek
Gupta
Kimpel

Cimpel

Kimpel

Ciesek

Conv $\mid \begin{aligned} & \text { Kimpe 1 } \\ & \text { Kimpe1 } \\ & \text { Kimpe 1 }\end{aligned}$
$1 \mathrm{~m}$ post 2 nd dose

$1 \mathrm{~m}$ post 2 nd dose

1m post 2 nd dose

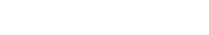

Az + Pfizer

2 *AZ

$2 \star$ Pfizer

Beta conv

Delta conv
Alpha conv

1m post 2nd dose

1m post 2nd dose

$1 \mathrm{~m}$ post 2 nd dose

$\mathrm{AZ}+$ Pfizer

$2 \star_{\mathrm{AZ}}$

$2 \star$ Pfizer

Alpha conv

Delta conv

Beta conv

Inf + Vacc

Vacc + Inf
$2 *$ Pfizer + Inf

$1 \mathrm{~m}$ post $3 \mathrm{rd}$ dose

$1 \mathrm{~m}$ post $3 \mathrm{rd}$ dose

$0.5 \mathrm{~m}$ post $3 \mathrm{rd}$ dose
$3 \mathrm{~m}$ post $3 \mathrm{rd}$ dose

$3 \mathrm{~m}$ post $3 \mathrm{rd}$ dose
$0.5 \mathrm{~m}$ post $3 \mathrm{rd}$ dose
$0.5 \mathrm{~m}$ post $3 \mathrm{rd}$ dose

$6 \mathrm{~m}$ post 2 nd dose

$1 \mathrm{~m}$ post 2 nd dose

$6 \mathrm{~m}$ post 2nd dose

$6 \mathrm{~m}$ post 2 nd dose

$1 \mathrm{~m}$ post 2 nd dose

$6 \mathrm{~m}$ post 2 nd dose

Im post 2nd dose

6m post 2nd dose

6m post 2 nd dose

$2 \star$ Pfizer + Pfizer

$2 *_{\mathrm{AZ}}+$ Pfizer

2 2*Moderna + Pfize

$\mathrm{A}+$ + Pfizer + Pfize

$2 *$ Pfizer + Pfizer

$2 *$ Pfizer

$2 *$ Pfizer

$2 \star \mathrm{AZ}$

$\mathrm{AZ}+\mathrm{Pfizer}$

${ }^{\star} \mathrm{AZ}$
$\mathrm{AZ}+$ Pfizer

$2 \star$ Pfizer

$2 \star$ Pfizer

$2 * \mathrm{AZ}$

$2 *$ Moderna

Beta conv

Alpha conv


Extended Data Figure 4: Omicron fold drops grouped by serum group relative to variants. A) Alpha (B.1.1.7; green), B) Beta (B.1.351; yellow) and C) Delta (B.1.617.2; orange). Same as Extended Data Figure 1, but datasets are grouped by serum group and fold drops calculated relative to variant titers. 
bioRxiv preprint doi: https://doi.org/10.1101/2021.12.31.474032; this version posted January 7, 2022. The copyright holder for this preprint (which was not certified by peer review) is the author/funder. All rights reserved. No reuse allowed without permission.

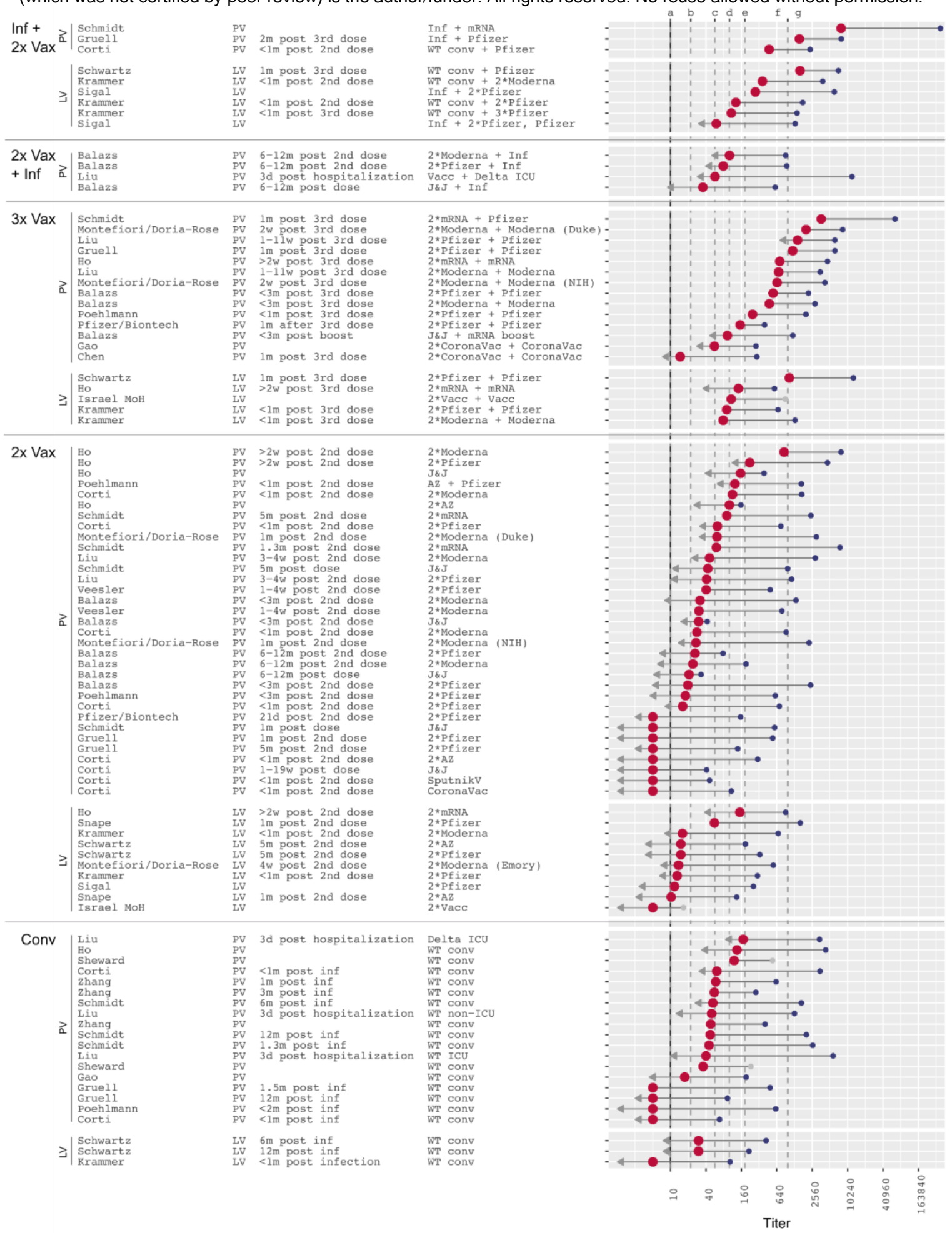

Extended Data Figure 5: Omicron titers grouped by serum type and assay relative to wild type and ordered by decreasing Omicron titers. Within each serum group, the datasets are subgrouped by assay type (LV: Live-virus, PV: Pseudovirus). Large red dots indicate Omicron titers and small colored dots indicate variant titers. Omicron titers were obtained by applying the fold drop given in Extended Data Figure 2 to variant titers, corresponding to the horizontal bar connecting point estimates. Variant titer data was either obtained from the manuscript or through Weplotdigitizer ${ }^{3}$ where not available. Arrows indicate uncertainties in the point estimate. A short arrow marks measurements with less than half of Omicron titers below the assay's limit of detection (LOD), or conversely reference antigen titers at or higher than the LOD. Long arrows mark measurements with more than approximately $80 \%$ of Omicron titers below the LOD. Dashed lines mark thresholds of protection against symptomatic disease after vaccination with two doses of Moderna (a,d,f,g) $)^{28}$ or AstraZeneca (b,c,e,f) ${ }^{27}$ assessed by pseudovirus neutralization assay (a 78\% VE, b 60\% VE, c $70 \%$ VE, d $91 \%$ VE, e $80 \%$ VE, f 90\% VE, g 96\% VE). Pink dots show NIH SAVE laboratories. 
bioRxiv preprint doi: https://doi.org/10.1101/2021.12.31.474032; this version posted January 7, 2022. The copyright holder for this preprint (which was not certified by peer review) is the author/funder. All rights reserved. No reuse allowed without permission.



Extended Data Figure 6: Omicron titers grouped by serum type and assay relative to wild type and ordered by decreasing wild type titers. Same as Extended Data Figure 5, but titers are ordered by decreasing wild type titers. 
bioRxiv preprint doi: https://doi.org/10.1101/2021.12.31.474032; this version posted January 7, 2022. The copyright holder for this preprint (which was not certified by peer review) is the author/funder. All rights reserved. No reuse allowed without permission.

A

\begin{tabular}{|c|c|c|c|}
\hline $2 \times \operatorname{Vax}$ & $\begin{array}{l}\text { Kimpel } \\
\text { Kimpel } \\
\text { Kimpel } \\
\text { Kimpel }\end{array}$ & $\begin{array}{l}\text { 1m post 2nd dose } \\
\text { 1m post 2nd dose } \\
4-6 \mathrm{~m} \text { post } 2 \text { nd dose } \\
\text { 1m post 2nd dose }\end{array}$ & $\begin{array}{l}\text { AZ Pfizer } \\
2 * \text { Pfizer } \\
2 * \text { Moderna } \\
2 * \mathrm{AZ}\end{array}$ \\
\hline Conv & $\begin{array}{l}\text { Kimpel } \\
\text { Kimpel } \\
\text { Kimpel }\end{array}$ & & $\begin{array}{l}\text { Alpha conv } \\
\text { Beta conv } \\
\text { Delta conv }\end{array}$ \\
\hline
\end{tabular}

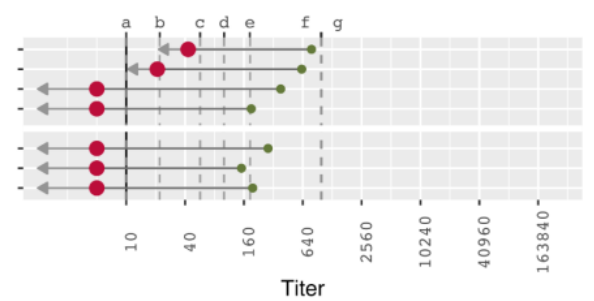

B

$$
\begin{array}{c|c}
2 x \text { Vax } & \begin{array}{l}
\text { Kimpel } \\
\text { Kimpel } \\
\text { Kimpel } \\
\text { Kimpel }
\end{array} \\
\text { Conv } & \begin{array}{l}
\text { Kimpel } \\
\text { Kimpel } \\
\text { Kimpel }
\end{array}
\end{array}
$$
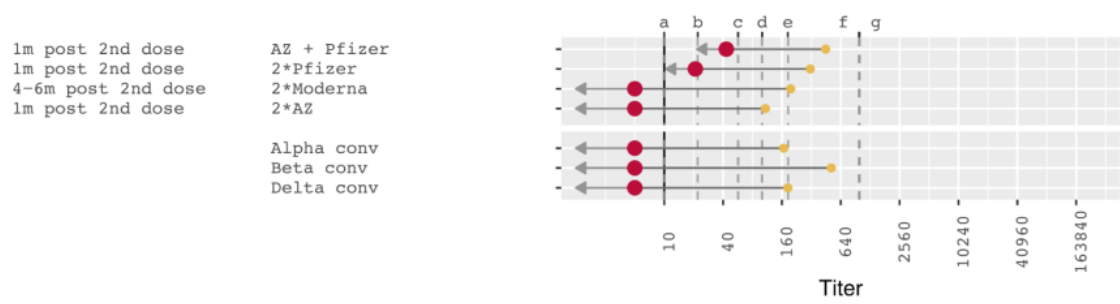

C
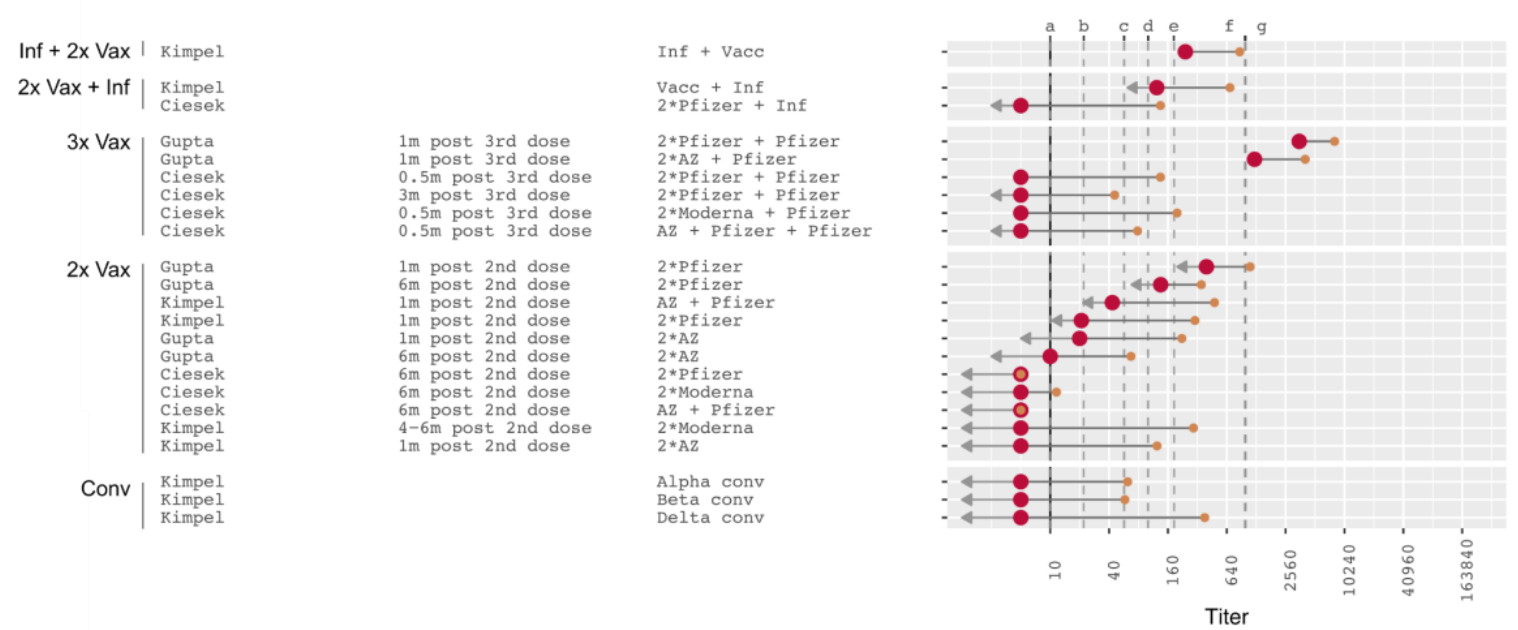

Extended Data Figure 7: Omicron titers grouped by serum group relative to variants and ordered by decreasing Omicron titers. A) Alpha (B.1.1.7; small green), B) Beta (B.1.351; small yellow) and C) Delta (B.1.617.2; small orange).Same as Extended Data Figure 5, but titers are grouped by serum grouped and calculated relative to SARS-CoV-2 variants. 
bioRxiv preprint doi: https://doi.org/10.1101/2021.12.31.474032; this version posted January 7, 2022. The copyright holder for this preprint (which was not certified by peer review) is the author/funder. All rights reserved. No reuse allowed without permission.

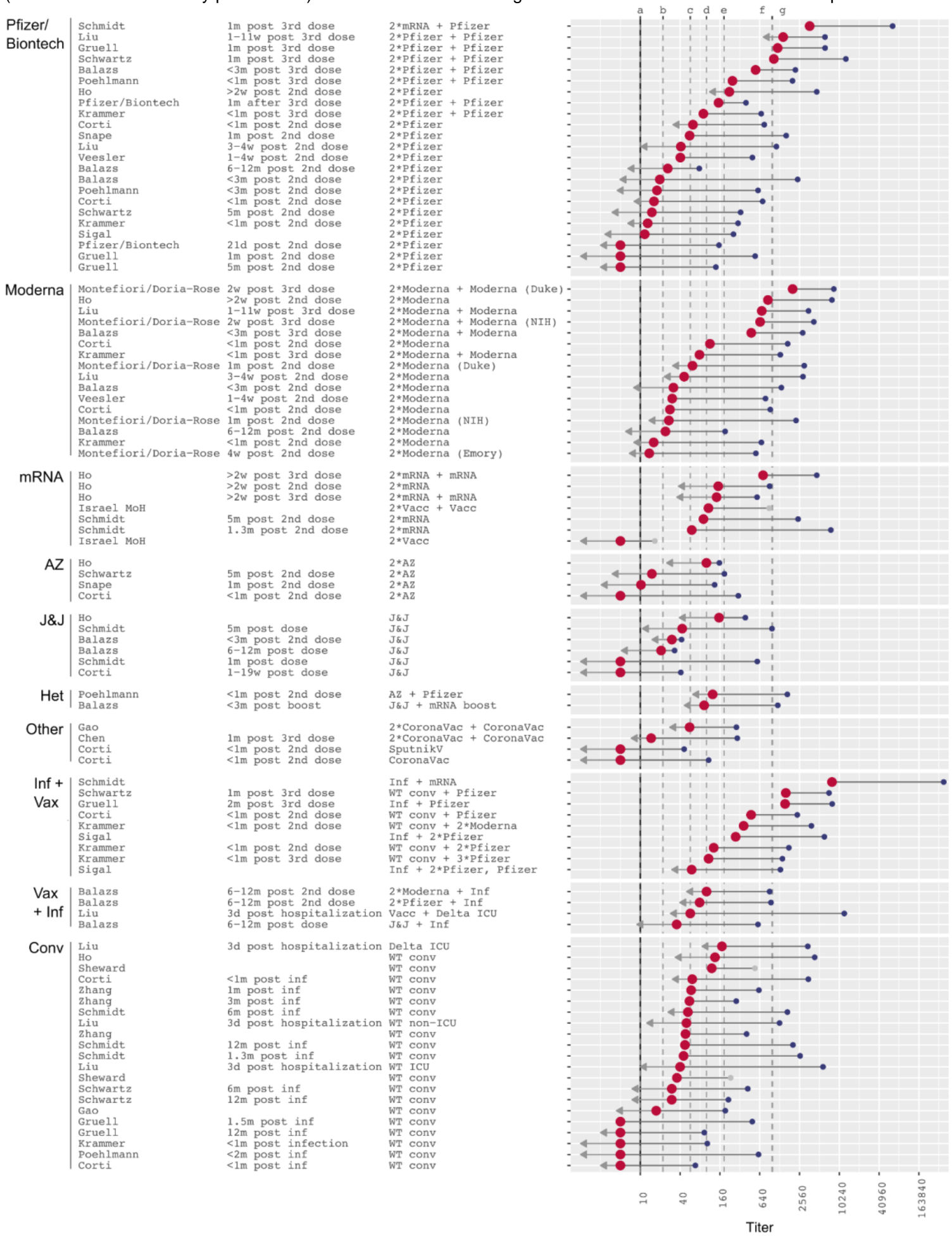

Extended Data Figure 8: Omicron titers grouped by vaccine type relative to wild type and ordered by decreasing Omicron titers. Same as Extended Data Figure 5, but titers are grouped by vaccine type. 
bioRxiv preprint doi: https://doi.org/10.1101/2021.12.31.474032; this version posted January 7, 2022. The copyright holder for this preprint (which was not certified by peer review) is the author/funder. All rights reserved. No reuse allowed without permission.

\begin{tabular}{|c|c|c|c|}
\hline $\begin{array}{l}\text { Pfizer/ } \\
\text { Biontech }\end{array}$ & \begin{tabular}{|l} 
Schmidt \\
Schwartz \\
Gruell \\
Liu \\
Ho \\
Balazs \\
Balazs \\
Poehlmann \\
Snape \\
Liu \\
Corti \\
Corti \\
Krammer \\
Poehlmann \\
Gruell \\
Veesler \\
Pfizer/Biontech \\
Schwartz \\
Krammer \\
Sigal \\
Pfizer/Biontech \\
Gruell \\
Balazs
\end{tabular} & 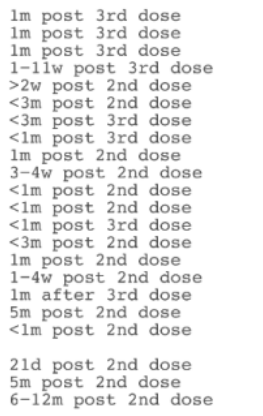 & 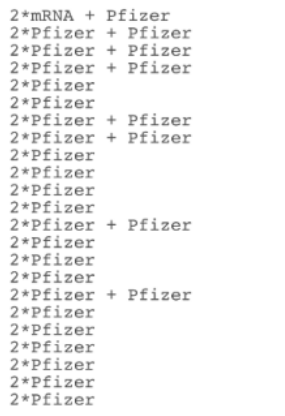 \\
\hline Moderna & $\begin{array}{l}\text { Montefiori/Doria-Rose } \\
\text { Ho } \\
\text { Montefiori/Doria-Rose } \\
\text { Liu } \\
\text { Montefiori/Doria-Rose } \\
\text { Liu } \\
\text { Balazs } \\
\text { Montefiori/Doria-Rose } \\
\text { Corti } \\
\text { Balazs } \\
\text { Krammer } \\
\text { Corti } \\
\text { Veesler } \\
\text { Krammer } \\
\text { Montefiori/Doria-Rose } \\
\text { Balazs }\end{array}$ & $\begin{array}{l}\text { 2w post } 3 \text { rd dose } \\
>2 \mathrm{w} \text { post } 2 \text { nd dose } \\
2 \mathrm{w} \text { post } 3 \text { rd dose } \\
1-11 \mathrm{w} \text { post } 3 \mathrm{rd} \text { dose } \\
1 \mathrm{~m} \text { post } 2 \text { nd dose } \\
3-4 \mathrm{w} \text { post } 2 \text { nd dose } \\
<3 \mathrm{~m} \text { post } 3 \mathrm{rd} \text { dose } \\
1 \mathrm{~m} \text { post } 2 \text { nd dose } \\
<1 \mathrm{~m} \text { post } 2 \text { nd dose } \\
<3 \mathrm{~m} \text { post } 2 \text { nd dose } \\
<1 \mathrm{~m} \text { post } 3 \mathrm{rd} \text { dose } \\
<1 \mathrm{~m} \text { post } 2 \text { nd dose } \\
1-4 \mathrm{w} \text { post } 2 \text { nd dose } \\
<1 \mathrm{~m} \text { post } 2 \text { nd dose } \\
4 \mathrm{w} \text { post } 2 \text { nd dose } \\
6-12 \mathrm{~m} \text { post } 2 \text { nd dose }\end{array}$ & $\begin{array}{l}2 \star \text { Moderna + Moderna (Duke) } \\
2 * \text { Moderna } \\
2 * \text { Moderna + Moderna (NIH) } \\
2 * \text { Moderna + Moderna } \\
2 * \text { Moderna (Duke) } \\
2 * \text { Moderna } \\
2 * \text { Moderna + Moderna } \\
2 * \text { Moderna (NIH) } \\
2 * \text { Moderna } \\
2 * \text { Moderna } \\
2 * \text { Moderna + Moderna } \\
2 * \text { Moderna } \\
2 * \text { Moderna } \\
2 * \text { Moderna } \\
2 * \text { Moderna (Emory) } \\
2 * \text { Moderna }\end{array}$ \\
\hline mRNA & $\begin{array}{l}\text { Schmidt } \\
\text { Ho } \\
\text { Schmidt } \\
\text { Ho } \\
\text { Israel MoH } \\
\text { Ho } \\
\text { Israel MoH }\end{array}$ & $\begin{array}{l}\text { 1.3m post } 2 \text { nd dose } \\
>2 \mathrm{w} \text { post } 3 \text { rd dose } \\
5 \mathrm{~m} \text { post } 2 \text { nd dose } \\
>2 \mathrm{w} \text { post } 2 \text { nd dose } \\
>2 \mathrm{w} \text { post } 3 \mathrm{rd} \text { dose }\end{array}$ & $\begin{array}{l}2 \star \text { mRNA } \\
2 \star \text { mRNA } \\
2 \star \text { mRNA } \\
2 \star \text { mRNA } \\
2 \star \text { Vacc }+ \text { Vacc } \\
2 \star \text { mRNA }+ \text { mRNA } \\
2 \star \text { Vacc }\end{array}$ \\
\hline$A Z$ & \begin{tabular}{|l} 
Corti \\
Schwartz \\
Ho \\
Snape
\end{tabular} & $\begin{array}{l}<1 \mathrm{~m} \text { post } 2 \text { nd dose } \\
5 \mathrm{~m} \text { post } 2 \text { nd dose } \\
1 \mathrm{~m} \text { post } 2 \text { nd dose }\end{array}$ & $\begin{array}{l}2 \star \mathrm{AZ} \\
2 \star \mathrm{AZ} \\
2 \star \mathrm{AZ} \\
2 \star \mathrm{AZ}\end{array}$ \\
\hline J\&J & $\begin{array}{l}\text { Schmidt } \\
\text { Schmidt } \\
\text { Ho } \\
\text { Balazs } \\
\text { Corti } \\
\text { Balazs }\end{array}$ & $\begin{array}{l}5 \mathrm{~m} \text { post dose } \\
1 \mathrm{~m} \text { post dose } \\
<3 \mathrm{~m} \text { post } 2 \text { nd dose } \\
1-19 \mathrm{w} \text { post dose } \\
6-12 \mathrm{~m} \text { post dose }\end{array}$ & $\begin{array}{l}J \& J \\
J \& J \\
J \& J \\
J \& J \\
J \& J \\
J \& J\end{array}$ \\
\hline Het & $\begin{array}{l}\text { Poehlmann } \\
\text { Balazs }\end{array}$ & $\begin{array}{l}<1 \mathrm{~m} \text { post } 2 \text { nd dose } \\
<3 \mathrm{~m} \text { post boost }\end{array}$ & $\begin{array}{l}\mathrm{AZ}+\text { Pfizer } \\
\text { J\&J + mRNA boost }\end{array}$ \\
\hline Other & $\mid \begin{array}{l}\text { Chen } \\
\text { Gao } \\
\text { Corti } \\
\text { Corti }\end{array}$ & $\begin{array}{l}\text { 1m post } 3 \text { rd dose } \\
<1 \mathrm{~m} \text { post } 2 \text { nd dose } \\
<1 \mathrm{~m} \text { post } 2 \text { nd dose }\end{array}$ & $\begin{array}{l}2 \star \text { Coronavac + CoronaVac } \\
2 \star \text { Coronavac }+ \text { CoronaVac } \\
\text { Coronavac } \\
\text { SputnikV }\end{array}$ \\
\hline $\begin{array}{l}\text { Inf }+ \\
\text { Vax }\end{array}$ & $\begin{array}{l}\text { Schmidt } \\
\text { Gruell } \\
\text { Schwartz } \\
\text { Sigal } \\
\text { Krammer } \\
\text { Corti } \\
\text { Krammer } \\
\text { Krammer } \\
\text { Sigal }\end{array}$ & $\begin{array}{l}\text { 2m post } 3 \text { rd dose } \\
\text { 1m post } 3 \text { rd dose } \\
\\
<1 \mathrm{~m} \text { post } 2 \text { nd dose } \\
<1 \mathrm{~m} \text { post } 2 \text { nd dose } \\
<1 \mathrm{~m} \text { post } 2 \text { nd dose } \\
<1 \mathrm{~m} \text { post } 3 \text { rd dose }\end{array}$ & $\begin{array}{l}\text { Inf }+ \text { mRNA } \\
\text { Inf }+ \text { Pfizer } \\
\text { WT conv }+ \text { Pfizer } \\
\text { Inf }+2 * \text { Pfizer } \\
\text { WT conv }+2 * \text { Moderna } \\
\text { WT conv }+ \text { Pfizer } \\
\text { WT conv }+2 * \text { Pfizer } \\
\text { WT conv }+3 * \text { Pfizer } \\
\text { Inf }+2 * \text { Pfizer, Pfizer }\end{array}$ \\
\hline $\begin{array}{l}\text { Vax } \\
+\operatorname{Inf}\end{array}$ & $\begin{array}{l}\text { Liu } \\
\text { Balazs } \\
\text { Balazs } \\
\text { Balazs }\end{array}$ & $\begin{array}{l}3 \mathrm{~d} \text { post hospitalization } \\
6-12 \mathrm{~m} \text { post } 2 \text { nd dose } \\
6-12 \mathrm{~m} \text { post } 2 \text { nd dose } \\
6-12 \mathrm{~m} \text { post dose }\end{array}$ & $\begin{array}{l}\text { Vacc }+ \text { Delta ICU } \\
2 \star \text { Pfizer }+ \text { Inf } \\
2 \star \text { Moderna }+ \text { Inf } \\
\text { J\&J + Inf }\end{array}$ \\
\hline Conv & \begin{tabular}{|l} 
Liu \\
Ho \\
Corti \\
Liu \\
Schmidt \\
Schmidt \\
Schmidt \\
Liu \\
Zhang \\
Poehlmann \\
Sheward \\
Gruell \\
Schwartz \\
zhang \\
2hang \\
Sheward \\
Schwartz \\
Gao \\
Krammer \\
Gruel1 \\
Corti
\end{tabular} & $\begin{array}{l}3 \mathrm{~d} \text { post hospitalization } \\
<1 \mathrm{~m} \text { post inf } \\
3 \mathrm{~d} \text { post hospitalization } \\
1.3 \mathrm{~m} \text { post inf } \\
12 \mathrm{~m} \text { post inf } \\
6 \mathrm{~m} \text { post inf } \\
3 \mathrm{~d} \text { post hospitalization } \\
1 \mathrm{~m} \text { post inf } \\
<2 \mathrm{~m} \text { post inf } \\
1.5 \mathrm{~m} \text { post inf } \\
6 \mathrm{~m} \text { post inf } \\
3 \mathrm{~m} \text { post inf } \\
12 \mathrm{~m} \text { post inf } \\
<1 \mathrm{~m} \text { post infection } \\
12 \mathrm{~m} \text { post inf } \\
<1 \mathrm{~m} \text { post inf }\end{array}$ & $\begin{array}{l}\text { WT ICU } \\
\text { WT conv } \\
\text { WT conv } \\
\text { Delta ICU } \\
\text { WT conv } \\
\text { WT conv } \\
\text { WT conv } \\
\text { WT non-ICU } \\
\text { WT conv } \\
\text { WT conv } \\
\text { WT conv } \\
\text { WT conv } \\
\text { WT conv } \\
\text { WT conv } \\
\text { WT conv } \\
\text { WT conv } \\
\text { WT conv } \\
\text { WT conv } \\
\text { WT conv } \\
\text { WT conv } \\
\text { WT conv }\end{array}$ \\
\hline
\end{tabular}

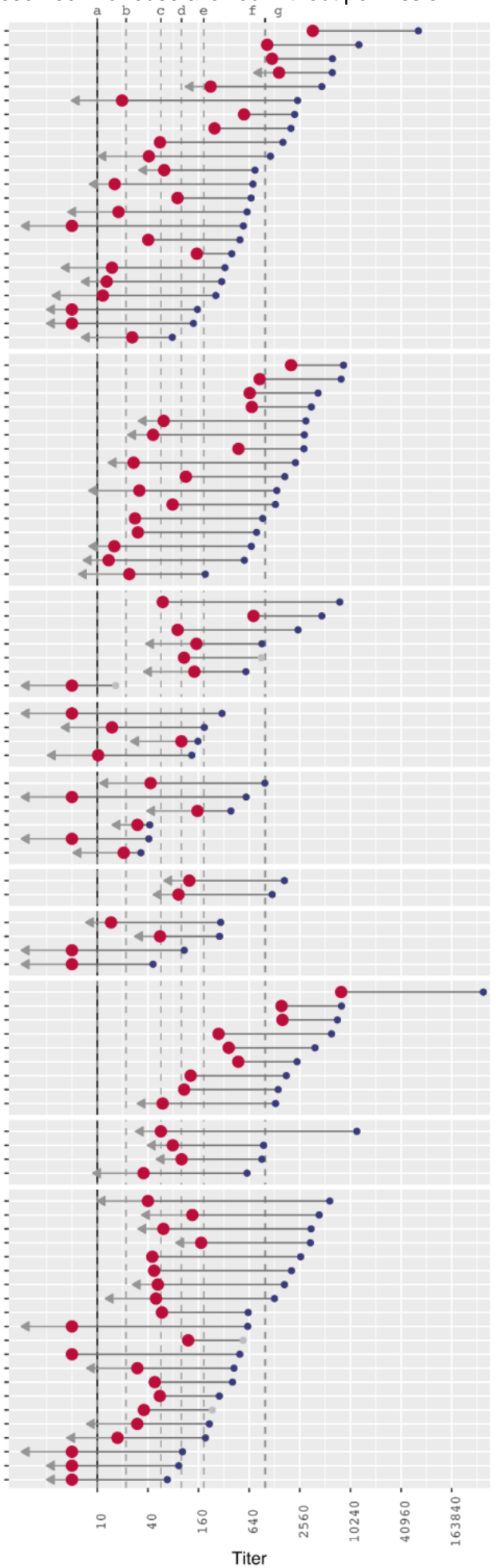

Extended Data Figure 9: Omicron titers grouped by vaccine type relative to wild type and ordered by decreasing wild type titers. Same as Extended Data Figure 5, but titers are grouped by vaccine type and ordered by decreasing wild type titers. 